University of New Hampshire

University of New Hampshire Scholars' Repository

Applied Engineering and Sciences Scholarship

Applied Engineering and Sciences

7-4-2015

\title{
Multinational perspectives on information technology from academia and industry
}

\author{
Mihaela C. Sabin \\ University of New Hampshire, Manchester, mihaela.sabin@unh.edu \\ John Impagliazzo \\ Hofstra University \\ Hala Alrumaih \\ Al Imam Mohammad Ibn Saud Islamic University \\ Brenda Byers \\ Canada's Association of IT Professionals \\ Daina Gudoniene \\ Vilnius University \\ Follow this and additional works at: https://scholars.unh.edu/unhmcis_facpub \\ Seomexeplatse for additional authors \\ (C) 2005, Association for Computing Machinery, Inc. This is the author's version of the work. It is posted here for your \\ personal use. Not for redistribution. The definitive Version of Record was published in Proceedings of the 2015 \\ ITiCSE on Working Group Reports, https://dx.doi.org/10.1145/2858796.2858802.
}

\section{Recommended Citation}

Mihaela Sabin, John Impagliazzo, Hala Alrumaih, Brenda Byers, Daina Gudoniene, Margaret Hamilton, Vsevolod Kotlyarov, Barry Lunt, James W McGu.ee, Svetlana Peltsverger, et al., Multinational perspectives on information technology from academia and industry, Proceedings of the 2015 ITiCSE on Working Group Reports, ACM, 2015, pp. 149-171.

This Article is brought to you for free and open access by the Applied Engineering and Sciences at University of New Hampshire Scholars' Repository. It has been accepted for inclusion in Applied Engineering and Sciences Scholarship by an authorized administrator of University of New Hampshire Scholars' Repository. For more information, please contact Scholarly.Communication@unh.edu. 


\section{Authors}

Mihaela C. Sabin, John Impagliazzo, Hala Alrumaih, Brenda Byers, Daina Gudoniene, Margaret Hamilton, Vsevolod Kotlyarov, Barry Lunt, James W. McGuffee, Svetlana Peltsverger, Cara Tang, Barbara Viola, and Ming Zhang 


\section{Multinational Perspectives on Information Technology from Academia and Industry}

\author{
Mihaela Sabin \\ Co-Leader \\ Computing Technology Department \\ University of New Hampshire \\ Manchester, New Hampshire 03101 USA \\ $+1.603 .641 .4144$ \\ mihaela.sabin@unh.edu
}

\author{
John Impagliazzo \\ Co-Leader \\ School of Engineering and Applied Sciences \\ Hofstra University \\ Hempstead, New York 11549 USA \\ $+1.631 .513 .2833$ \\ John.Impagliazzo@hofstra.edu
}

\author{
Hala Alrumaih \\ College of Computer and Information \\ Sciences \\ Al Imam Mohammad Ibn Saud Islamic \\ University (IMSIU) \\ Riyadh, Saudi Arabia \\ +966.5054.96409 \\ hala.alrumaih@ccis.imamu.edu.sa
}

Margaret Hamilton

School of Computer Science \& IT RMIT University GPO Box 2476V

Melbourne, Australia, +61.3.9925.2939

margaret.hamilton@rmit.edu.au

\section{James W. McGuffee}

Computer Science Department

Northern Kentucky University

Highland Heights, Kentucky 41099

USA

$+1.859 .572 .7931$

mcguffeej1@nku.edu

\author{
Brenda Byers \\ National Board Chair, CIPS \\ Canada's Association of IT \\ Professionals \\ 255 Beechdale Court \\ Saskatoon, SK, Canada \\ $+1.306 .260 .0361$ \\ brenda@cips.ca
}
Vsevolod Kotlyarov Institute of Computer Science and Technologies
Peter the Great Polytechnic University
St. Petersburg, Russia +7.921.953.0809 vpk@spbstu.ru
Svetlana Peltsverger
Department of Information Technology
Kennesaw State University Marietta, Georgia
+1.678.915-4285
speltsve@kennesaw.edu

\author{
Daina Gudoniene \\ Vilnius University \\ Akademijos 4, LT-08663 Vilnius \\ Kaunas University of Technology \\ Studentu 50, LT-51367 Kaunas, \\ Lithuania \\ +370.61858604 \\ daina.gudoniene@mii.stud.vu.It
}

$$
\begin{gathered}
\text { Barry Lunt } \\
\text { School of Technology } \\
\text { Brigham Young University } \\
\text { 265 CTB } \\
\text { Provo, Utah 84602 USA } \\
+1.801 .422 .2264 \\
\text { luntb@byu.edu } \\
\text { Cara Tang } \\
\text { Computer Information Systems } \\
\text { Portland Community College } \\
\text { Portland, Oregon } 97219 \text { USA } \\
+1.971 .722 .4447 \\
\text { cara.tang@pcc.edu }
\end{gathered}
$$

Barbara Viola

Association of Information Technology

Professionals (AITP)

Viotech Solutions Inc.

1111 Route 110, Suite 362

Farmingdale, New York 11735 USA

$+1.631 .630 .4640$

bviola@viotechsolutions.com
Ming Zhang

School of EECS

Peking University

100871, Beijing, China

$+86.10 .62765825$

mzhang@net.pku.edu.cn 


\begin{abstract}
As the term 'information technology' has many meanings for various stakeholders and continues to evolve, this work presents a comprehensive approach for developing curriculum guidelines for rigorous, high quality, bachelor's degree programs in information technology (IT) to prepare successful graduates for a future global technological society. The aim is to address three research questions in the context of IT concerning (1) the educational frameworks relevant for academics and students of IT, (2) the pathways into IT programs, and (3) graduates' preparation for meeting future technologies. The analysis of current trends comes from survey data of IT faculty members and professional IT industry leaders. With these analyses, the IT Model Curricula of CC2005, IT2008, IT2017, extensive literature review, and the multinational insights of the authors into the status of IT, this paper presents a comprehensive overview and discussion of future directions of global IT education toward 2025.
\end{abstract}

\section{Categories and Subject Descriptors}

- General and reference Surveys and overviews • Social and professional topics Model curricula - Social and professional topics Information technology education

\section{Keywords}

International IT curriculum; educational pathways; IT industry perspective; IT faculty perspective

\section{INTRODUCTION}

The research reported in this paper generates from an ACM/IEEE effort to update the IT2008 Curriculum Guidelines for Undergraduate Degree Programs in Information Technology [41], presently targeted to be the IT2017 model curriculum. The authors, part of Working Group 6 at ITiCSE 2015, focused on being forward thinking to capture both the current and future changes in IT.

Information technology (IT) means different things for different stakeholders. These stakeholders include industry and business sectors, academic institutions, professional and scientific societies, and students graduating from high school or technical schools interested in pursuing undergraduate degrees in IT. The academia-industry dimension is compounded by the geographic factor. High-tech professional organizations have international membership. IT degree programs are omnipresent. IT industry advances at fast pace worldwide.

To address the very large issue of multinational perspectives on IT education, the work in this paper centers on three research questions that now follow.

\section{What commonalities and differences do IT curricular}

Permission to make digital or hard copies of all or part of this work for personal or classroom use is granted without fee provided that copies are not made or distributed for profit or commercial advantage and that copies bear this notice and the full citation on the first page. Copyrights for components of this work owned by others than the author(s) must be honored. Abstracting with credit is permitted. To copy otherwise, or republish, to post on servers or to redistribute to lists, requires prior specific permission and/or a fee. Request permissions from permissions@acm.org.

ITICSE-WGR'15, July $04-08,2015$, Vilnius, Lithuania

Copyright is held by the owner/author(s). Publication rights licensed to ACM. ACM 978-1-4503-4146-2/15/07 ..\$15.00 DOI:

http://dx.doi.org/10.1145/2858796.2858802 frameworks have in academic institutions worldwide? Bachelor's academic programs frame their IT curriculum in light of their institutional mission, characteristics of their student population, and employer expectations. In addition to location, other differentiating factors include size, emphasis on post-bachelor's education, and student diversity of academic institutions.

What are the pathways into and through undergraduate IT degree programs in various parts of the world?

Multiple factors such as admission criteria, student academic preparedness and diversity, life experiences, and different configurations of educational pathways shape access, retention, and degree attainment across bachelor's academic programs in IT.

What is the future of IT?

The computing landscape is changing fast. Discoveries in university laboratories and $\mathrm{R} \& \mathrm{D}$ departments and industrial technological advances transform every global economic sector and society. New developments and resources are becoming available and too many sources of information will become a real challenge for the future.

In attempting to answer these queries, more questions emerged, which we elaborated on further in this research study.

\section{INFORMATION TECHNOLOGY IN CONTEXT}

People have dubbed this modern era as the 'information age' with reference to previous ages such as the Stone Age and the Iron Age. Indeed, wide access to computing and communication technologies has dramatically enhanced the technological progress of humankind, enabling the creation of many new technologies. Originally, IT consisted of very specialized and expensive computing and communication technologies, available to a relatively small portion of society. Early academic disciplines in this field included computer science, information systems, and electrical engineering.

\subsection{Current definition of IT}

There are many definitions of the term "information technology". A current definition of IT should include perspectives of globalization; multinational, multicultural and multidisciplinary teamwork; the importance of people (soft) skills, best practices, frameworks, and regulations. The definition from the 2008 IT Model Curriculum is relevant:

"Information Technology (IT) in its broadest sense encompasses all aspects of computing technology. IT, as an academic discipline, is concerned with issues related to advocating for users and meeting their needs within an organizational and societal context through the selection, creation, application, integration and administration of computing technologies." [41]

Margaret Rouse states, "Information technology (IT) is a general term that covers all forms of technology used to create, store, exchange, and use information in various forms" [57]. An even more expansive definition is, "Information technology (IT) is the application of computers and telecommunications equipment to store, retrieve, transmit and manipulate data, often in the context of a business or other enterprise [17]. 
These definitions seem to convey the all-inclusive, everexpanding and integrative role of IT by organizations in our society. Academia on the other hand, views information technology as a path leading to an endpoint that "represents a fundamental change in the basic technology of teaching and learning" or as "...undergraduate degree programs to meet the computer technology needs of business, government healthcare, schools, and other kinds of organizations" [45].

\subsection{Future definition of IT}

If we back up over a hundred years and ask what the definition of electricity might entail, with today's hindsight we could say that electricity would become an enabling technology for the advancement of civilization, and that it would enable dramatic developments in all areas of civilization, even enabling the creation of previously unknown domains. Applying this to IT, we see the emergence of the internet and the web as major enablers of easy information access for all individuals (not just the cognoscenti) in all developed countries. This widespread information access has become an enabler for an increasing range of domains.

A recent study by the Bureau of Labor Statistics (BLS) shows that computer and mathematical occupations expect to increase by $17.7 \%$ by 2022 . Software developers and programmers will account for 4 out of 10 new jobs in this group. The fastest projected growth of $36.5 \%$ will be for information security analysts [7]. All of the computer and mathematical occupations typically require some level of college education, and more than 3 in 4 new jobs in this group are projected to be in occupations that require at least a bachelor's degree. The dynamics of future computing occupations contributes directly to the definition of IT.

\subsection{Global Perspective}

Does IT mean the same thing around the world? In terms of business, research into various technology hubs worldwide seems to confirm these basic definitions. In some countries, including Saudi Arabia, the view of IT is very similar to what we have in the US [12]. Germany is one of the countries that emphasize broadcasting technologies as a part of IT. They use the term information and communication technologies (ICT) to add audiovisual production, telephone and wireless communications [23].

In looking at Israel, their emphasis on all technology and focus on IT has made them an industry leader worldwide. "Israel is home to major players in the high-tech industry and has one of the world's most technologically literate populations" [60]. It is of interest that Google Chairman Eric Schmidt said, “...Israel has the most important high-tech center in the world after the US"1. Similarly, in South Korea, Bloomberg News ranked South Korea number one among all nations, "...comparing a group of indicators, such as research \& development capability, productivity, tech density and patent activity" [46]. Not surprisingly, South Korea has the highest “...broadband penetration in the world at $97 \%$ and is a leader in broadband speed". This is a key indicator of the role and expansion of IT in its broad definition, within their country.

China has placed special emphasis on funding for IT and research and this has resulted in national growth in this area. "IT covers a wide range of industries such as hardware, software, electronics, semiconductors, internet, telecom equipment, e-commerce, and unlimited computing services" [66]. During the last several years, Mexico has reached a more important role in the growing world industry of IT by including a wide range of products to become "the relevant variable of the knowledge society and the main driver of our times' technological and communications revolution" [10]. IT in Japan focuses on development a business strategy that utilizes IT ensuring the stable operation of the information systems to create safe and reliable service-driven industry [4].

Many developing countries including Brazil see IT as a way to create a competitive and innovative environment to promote economic development of the country [3]. The government of many developing countries support IT initiatives and make large capital investments in IT infrastructure. For example, Kazakhstan at the beginning of 2013 started a government program 'Informational Kazakhstan - 2020' [25] The program represents a strategy for further development of ICT in Kazakhstan and computerization of processes in all sectors of the economy. Chile's government has already integrated technology in education, business and government. Recently the country created a Ministry of Science and Technology to "lay the foundations to compete as a country on an equal footing with the rest of the world" [28]. For many countries in Africa, IT is more about consumption than innovation and "the knowledge acquired through the internet has already transformed several lives in the poverty-stricken areas of Africa" [36].

In understanding of the global similarity of IT, a review of leading job websites, such as http://indeed.com, shows that the same global companies (IBM, Microsoft, Cisco, Intel, etc.) hire IT professionals around the world and have the same requirements in all countries. Indeed.com aggregates job listings from different websites, including job boards, staffing firms, associations, and company career pages. The site has 180 million unique visitors every month from over 50 different countries in 28 languages.

\section{SURVEY METHODOLOGY}

An important question of computing disciplines is the way people come to understand computing and ways to make it better [15]. Social context is important in exploring how IT curricular frameworks reflect and respond to factors specific to the academic institutions of the IT undergraduate degree programs [62]. To gain insights into what IT discipline and profession mean to academia and industry, the authors designed two online surveys, for computing faculty and IT professionals. With support from ACM, the surveys were administered in spring of 2015.

Survey participants were faculty members in computing departments around the world and IT professionals who are members of the Association of Information Technology Professionals (AITP). The purpose of the surveys was to evaluate the curricula of undergraduate IT degree programs that prepare highly competitive IT graduates. Data in the Integrated Postsecondary Education Systems [51] identified participating academic computing programs in the U.S. ACM identified nonU.S. academic programs. One working group member reached out to the AITP to administer the IT professional survey.

The design of the faculty survey appears in Appendix A.1. It has taken into account institutional and curriculum constructs, each having four elements.

\footnotetext{
${ }^{1}$ http://www.israel21c.org/google-chair-eric-schmidtrecommends-investing-in-israel/
} 


\section{Institutional constructs}

1. Location (North America, Europe, Australia/New Zealand, South America, South/Southeast/East Asia, South Africa)

2. Size of the academic IT program (as measured by the number of graduates)

3. Emphasis on post-bachelor's education (as measured by the presence of graduate programs and percentage of students who continue in grad schools)

4. Sources of external student transfers

IT curriculum constructs

5. Areas of mathematics and science subjects (believed to be necessary and actually required) and number of required math and science courses

6. Credit-bearing internship experience

7. Percentage of technical IT component of the full undergraduate degree program

8. IT knowledge areas of importance

The IT industry survey appears in Appendix B.1. It has a similar but simpler design compared to the IT faculty survey. It includes the following.

Institutional constructs

1. Location

2. Size of the IT department (as measured by the number of employees)

\section{IT curriculum constructs}

3. Areas of mathematics and science subjects (believed to be necessary)

4. IT knowledge areas of importance

5. IT graduates' skill sets of importance

The faculty survey was hosted by ACM on the Survey Monkey platform and distributed through several email blasts to the ACM membership. The survey asked 16 questions with a mix of multiple-choice and free form responses ${ }^{2}$. Two email blasts to contacts acquired from the International Book Information Service (IBIS) and one email blast to members of the ACM Special Interest Group for Information Technology Education produced 540 responses. The first IBS blast, in April 2015, went to 3,000 U.S. faculty members and 7,000 international faculty members from countries in Africa, Asia, Australia, Europe, and the Americas. A second blast in May 2015 targeted a different sampling of unique contacts from the same IBIS list, this time reaching 1,500 U.S. faculty members and 3,500 international faculty members.

To supplement response from U.S. programs, the survey was also posted to IT faculty from a contact list compiled by a research study on the IT faculty profile [43] (approximately 900 contacts of IT faculty in the U.S., some of whom are SIGITE members). This survey outreach resulted in additional 42 responses. Further, due to an apparent lack of response from programs based in China to the IBIS mailings, two working group members distributed a Chinese translation of the survey to participants of an IT2017 workshop in Chengdu and at another workshop in Beijing taking place in spring 2015 . With 15 responses from this venue, the total survey responses were 597 (about $3.8 \%$ response rate).

\footnotetext{
2 http://www.acm.org/education/it2017_survey.pdf/
}

For the industry survey (Appendix B.1), leaders of AITP emailed the survey to approximately 1,870 of its members with 93 respondents ( $5 \%$ response rate).

The survey responses were given routine data cleaning by a statistician to eliminate spurious responses, to correct typographical errors and expand common abbreviations in freetext responses, and to recode "other" responses into admissible answers when possible. Appendices A.2 and B.2 have summaries of the faculty and industry survey results.

In trying to ascertain the multinational breadth of IT curriculum frameworks, the authors investigated the survey results in the context of a literature review of previously published pedagogical work. The review of literature yielded results that were consistent with survey results. Additionally, certain findings from the survey led to investigative search terms in the literature review.

The group also investigated pathways toward a bachelor's degree in IT and considered the rigor of IT programs. The group defined a "demanding" program as one that requires some sciences beyond general education, three or more math courses, and in which more than $50 \%$ of the program is technical. It hypothesized that fewer students transfer into demanding programs as compared with transfers into non-demanding programs. If a program is too demanding, students may be less likely to graduate. Another factor we examined is the diversity of educational background. If there are many students transferring into the program from a variety of academic backgrounds, then such a group might be less likely to succeed.

The working group researched the extent to which characteristics of academic institutions correlate with characteristics of IT curriculum requirements such as required internship, size of the IT portion of the degree, and math and science course requirements. The hypotheses of interest in this study were:

a. Internship experience is highly valued in IT programs.

b. Programs with IT components that represent $65 \%$ or more of the full undergraduate degree program require more math and science courses.

c. Programs that are "demanding" have fewer transfer students,

d. Small companies pay more attention to applied calculus and linear algebra than big companies, while the latter care about probability and statistics more,

e. IT industry values social skills.

The working group also compared faculty and IT professionals' responses to evaluate the degree of match between what academic institutions and industry expect of IT degree programs.

To investigate the future of IT, the working group decided to use elements such as indicators and surveys, predictors, and information related to IT departments. One approach was the use of the results of the IT2017 industry survey to garner information on the future of IT. Specifically, it focused on the query that stated, "Indicate the top six skill sets you believe your organization will require of new IT graduates in the mid-2020s." The survey presented thirteen choices that included project management, cloud computing, data analytics, database, administration and architecture, information (cyber) security, quality assurance, $\mathrm{PC} /$ desktop support, networking, programming, help desk support, soft skills, and rudiments of finance. A provision for "Other" was also possible. Several chief information officers (CIOs) developed these skill sets. 
The working group also recognized that it was important to establish reliable predictors on the future of IT and explored the specific organizations that studied future trends and patterns for commercial industries. Two sources clearly emerged, namely the Gartner Group ${ }^{3}$ and Forbes ${ }^{4}$. These and other sources were useful in predicting patterns for the future of computing and IT. The group found many discussions about strategic IT predictions during the research. The question remains relevant, namely: are there reliable predictors of what IT will look like in 2025? The main considerations are what will be important for future of IT. The group considered customer demand (for creating more data), industry demand (for analyzing data), and privacy and security issues.

\section{RESULTS AND DISCOVERY}

\subsection{Curricular Frameworks}

Information technology is a very broad and diverse field. Because of the diversity, it should be possible for any student from any background to map their own career path through the many topics provided in the IT curriculum; the curriculum should be capable of expanding to include the next latest new technologies. However, because of this diversity, it is also very difficult for academics to define clear requirements for a degree. In this paper, we present our research into where we believe IT education should be in the 2020s.

The CC2005 Overview Report [11] compares five computing programs that have produced model curricula. It provides an explanation of information technology as described in 2005. In their paper, Ekstrom and Lunt [22] noted several implications for IT pedagogy into the future. Williams [64] stressed the importance of incorporating the requirements of hiring IT personnel and corporate research agendas into the IT programs. Impagliazzo and McGettrick [30] considered new models and integrative approaches for developing a curriculum from an organization point of view. Degree programs in IT arose because degree programs in other computing disciplines were not producing an adequate supply of graduates capable of handling these very real needs [42]. IT programs exist to produce graduates who possess the right combination of knowledge and practical, hands-on expertise to take care of an organization's IT infrastructure and support and assist the people who use IT solutions [31, 37, 38].

\subsubsection{Global Perspectives}

In looking at IT academic programs globally, we noted a wide variety of approaches to teaching this discipline. Many countries, including Saudi Arabia and China, follow IT2008 curriculum [41], while other countries have their own perspectives based on their national IT industry needs. IT education has become a high priority area for the Chinese government due to China emerging as one of the most dynamic IT markets in the world. The Ming Zhang and Long Zhang [66] introduced the progress, objectives and curricula of eight IT-related programs at the bachelor's level. In Saudi Arabia, IT programs focus on areas far beyond programming or immersive software development, and integrate an intense exposure to mathematics and science to generate strong critical thinking graduates. In addition, programs provide the potential to conduct projects, internships, and research together with an emphasis on training components to enhance the practical experience of students. IT programs also foster adaptability to

\footnotetext{
${ }^{3} \mathrm{http}: / /$ www.gartner.com/technology/home.jsp

${ }^{4} \mathrm{http}: / /$ www.forbes.com/forbesinsights/
}

change in job market needs by providing in-depth knowledge through specific concentrations that are easily interchangeable [32]. Hence, respected IT programs in Saudi Arabia have enjoyed success with these principles and they serve as models for other IT programs in the region to emulate.

The growing need for IT graduates in Canada is raising concerns [44]. Compounding this challenge is an ICT sector unemployment rate of three per cent versus the national average of 7.5 per cent for all other sectors and the continued emergence of ICT sectors in segments such as the mobile arena, cloud computing and creative online content [2]. Canada's universities make use of advisory councils to inform their computer science curricula. Canada's post-secondary colleges and institutes look to industry as well for guidance on IT curriculum learning outcomes and related content, particularly when designing for the actual IT skills set.

Interestingly, in some countries such as Japan, IT as a discipline consists of several categories: strategist, system architect, project manager, service manager, global specialist and business architect [4]. The degree "010300 bachelor programming and information technologies" approved by the Russian Education Council focuses on "developing efficient computational methods and technologies, intended for implementation using parallel, distributed information resources, modeling, improvement, and maintenance of distributed information and computer systems based on advanced mathematical methods, and on efficient computer technologies" [18].

IT education in Finland has the emphasis on software engineering, communication networks and applications, smart systems, and mobile solutions [1]. In Argentina, Information Technology engineering prepares students "to define and assess projects in terms of requirements of hardware, software based and application, human resources, costs and efficiency at management" [34]. The degree specifically emphasizes that the graduates will control projects from very beginning until the final implementation. Universities in Germany recognize that "information technology has become a vast field that they cannot wholly cover by the classic programs of informatics or electrical engineering anymore" [23].

Bowen and Spohrer [5] report that both computer technology and the IT industry have undergone dramatic change and this requires that IT education must also undertake dramatic change. Cooper, Grover, and Guzdial [15] observe that "The economic value of knowing computing is greater than any other STEM field, but computing is the least diverse of all the STEM fields. Thus, too many people are losing out on the advantages of computing. We have to figure out how to fix that, while still answering the fundamental questions of our discipline. How do people come to understanding computing, and how can we make it better?" IT education is very important worldwide. As the IT industry is constantly evolving and new technologies continuously emerge, IT jobs are evolving and new positions created. "The new technologies create new ICT positions ... ICT graduates today can pursue a large range of ICT careers" [8].

The structure and format of IT programs vary significantly from institution to institution and by country (Table 4.1). For example, in Saudi Arabia, King Saud University [14] and Al Imam Mohammad Ibn Saud Islamic University [32] require five mathematics courses, which represent about $14 \%$ of total of IT program credit hours. These courses include topics in discrete structures, calculus, linear algebra and differential equations, and 
probability \& statistics. Both universities require only one science course, which is general physics that forms about $3 \%$ of the total of IT program credit hours. IT courses represent $45-49 \%$ of total of IT program credit hours in these universities.

Table 4.1. Structure of IT programs in different countries

\begin{tabular}{|l|l|c|c|c|c|}
\hline $\begin{array}{l}\text { University } \\
\text { Name }\end{array}$ & Country & $\begin{array}{c}\text { Total } \\
\text { credit } \\
\text { hours }\end{array}$ & $\begin{array}{c}\text { Math } \\
\text { courses } \\
\text { credit } \\
\text { hours }\end{array}$ & $\begin{array}{c}\text { Science } \\
\text { courses } \\
\text { credit } \\
\text { hours }\end{array}$ & $\begin{array}{c}\text { IT } \\
\text { course } \\
\text { credit } \\
\text { hours }\end{array}$ \\
\hline $\begin{array}{l}\text { King } \\
\text { Saud } \\
\text { University }\end{array}$ & $\begin{array}{l}\text { Saudi } \\
\text { Arabia }\end{array}$ & 131 & 15 & 4 & 64 \\
\hline $\begin{array}{l}\text { Al Imam } \\
\text { University }\end{array}$ & $\begin{array}{l}\text { Saudi } \\
\text { Arabia }\end{array}$ & 132 & 18 & 3 & 60 \\
\hline $\begin{array}{l}\text { University } \\
\text { of } \\
\text { Cincinnati }\end{array}$ & $\begin{array}{l}\text { United } \\
\text { States }\end{array}$ & 120 & 11 & 6 & 72 \\
\hline $\begin{array}{l}\text { Purdue } \\
\text { University }\end{array}$ & $\begin{array}{l}\text { United } \\
\text { States }\end{array}$ & 120 & 9 & 6 & 52 \\
\hline
\end{tabular}

In the United States for example, the University of Cincinnati in Ohio [33] requires three mathematics courses, which represent $9 \%$ of total of IT program credit hours. These courses include topics about discrete math, pre-calculus, and applied statistics. Students must complete 6 hours of science electives from the biology, chemistry, physics or geology discipline that form $5 \%$ of the total IT program. For the IT courses, they represent $60 \%$ of total of IT program credit hours.

Purdue University in Indiana [56] requires three mathematics courses, which represent $8 \%$ of total of IT program credit hours. These courses include topics in applied calculus, and statistics. The university has two selective science courses that form $5 \%$ of total of IT program credit hours. IT courses represent $43 \%$ of total of IT program credit hours.

From these examples, we can conclude that Saudi Arabia universities have a greater emphasis on mathematics courses while universities in the United States have a greater emphasis on science courses. The percent of IT courses varies from institution to institution regardless of country. Table 4.1 shows a summary of these findings.

\subsubsection{Survey Results}

\subsubsection{Institutional Size and Geographic Location}

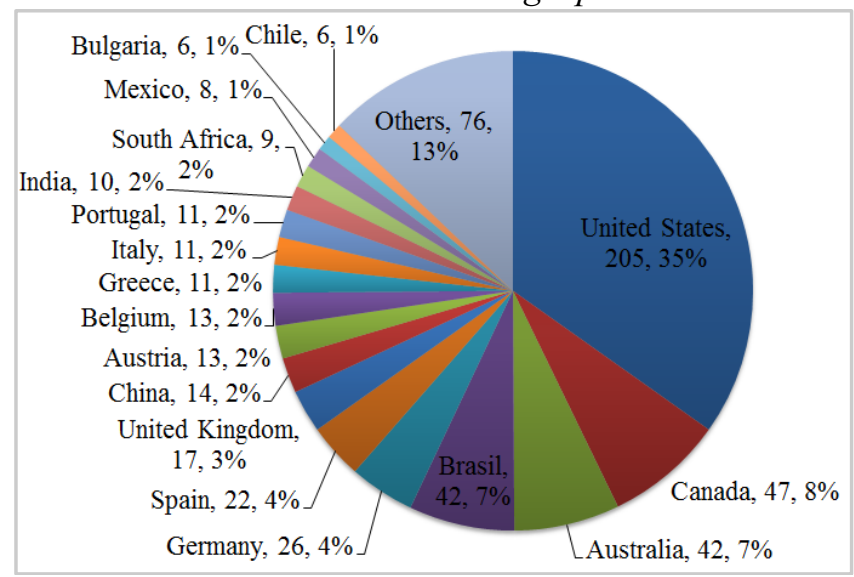

Figure 4.1. Country of origin of academic institutions of faculty respondents
The 589 faculty members who participated in the faculty survey came from 50 countries, $34.8 \%$ from U.S. and $65.2 \%$ from nonU.S. countries. Participation from top ten countries amounted to $75 \%$ of all participants (Figure 4.1 ).

Data from the industry survey show that almost all industry respondents (91 IT professionals) were from U.S. (98.9\%).

A majority of academic institutions (53.3\%) had less than 100 graduates from their IT degree programs in the past year, and few academic institutions $(12.9 \%)$ graduated more than 300 students (Figure 4.2).

A large majority of IT departments who participated in the IT professional survey had less than 30 employees (65\%) and $30 \%$ were large IT departments with more than 100 employees (Figure 4.3).

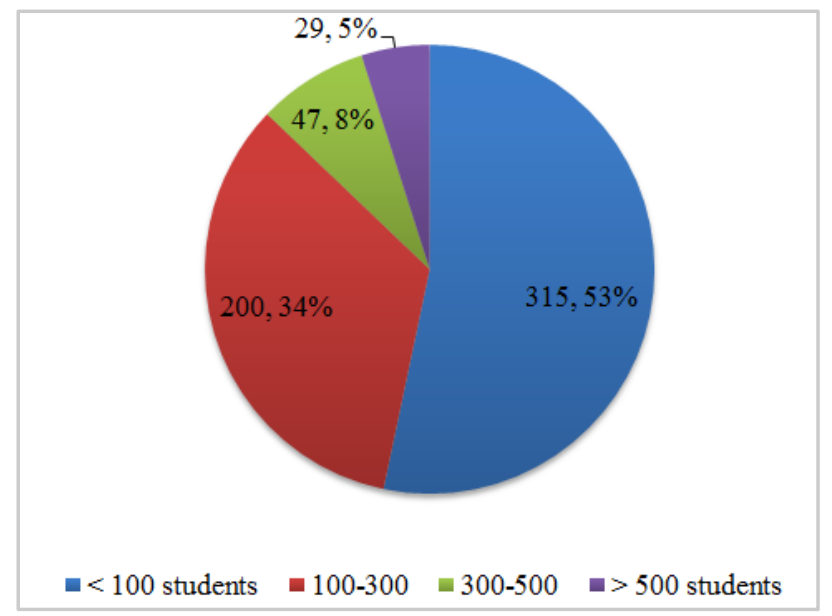

Figure 4.2. Size of IT academic programs based on the number of graduates in 2014-2015

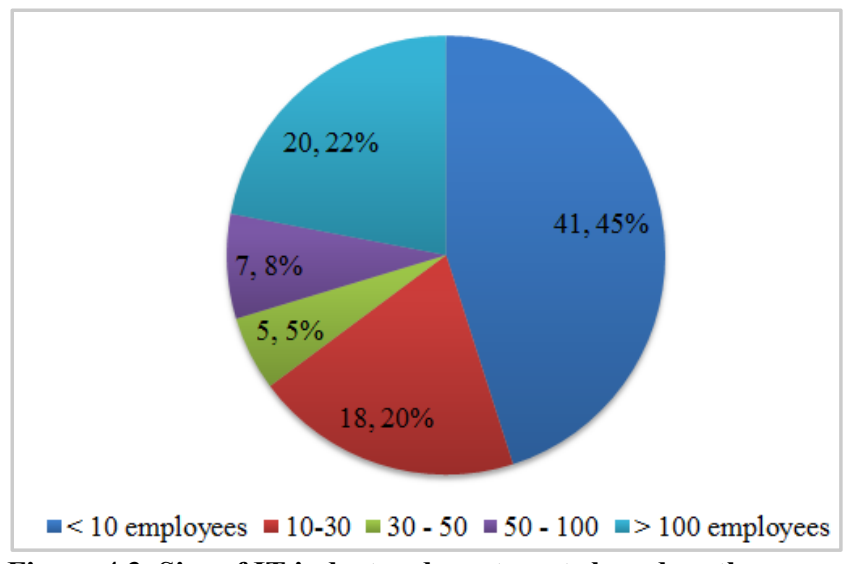

Figure 4.3. Size of IT industry departments based on the number of employees

\subsubsection{Transfer Students and Post-Baccalaureate Education}

Of the 589 respondents to the faculty survey, 537 answered the question regarding sources of external transfer students into an undergraduate IT program. As shown in Figure 4.4, approximately one-third of respondents have no significant number of transfer students; one-third has two- or three-year technical or community colleges as the primary source of transfer 
students. Less than $10 \%$ of respondents indicated the primary source of transfer students as being due to life experiences or industry-university articulation agreements, respectively.

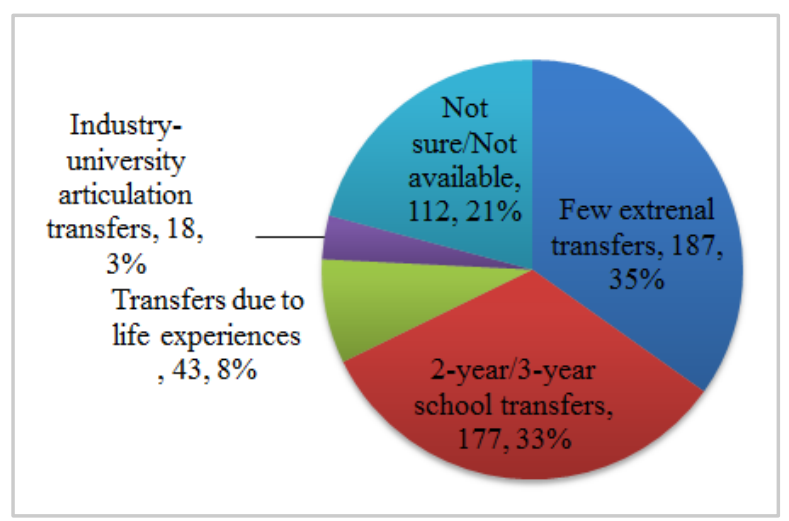

Figure 4.4. Sources of transfer students into IT academic programs

A majority of academic institutions (54\%) had fewer than $10 \%$ of their graduates continue in graduate school in the past year as illustrated in Figure 4.5.

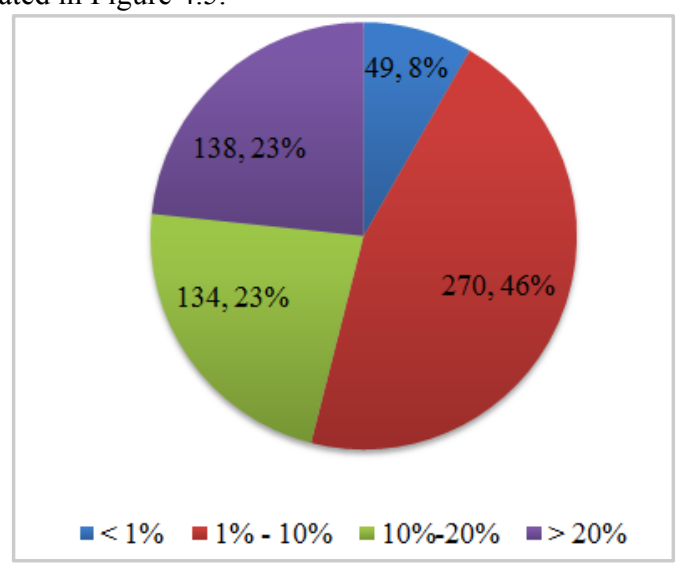

Figure 4.5. Students in IT academic programs continuing to graduate school

\subsubsection{Mathematics Requirements}

The faculty survey included the question "Which areas of mathematics does your program currently require to produce a competent IT graduate?" (Appendix A.1, F7), followed by a list of seven prompted mathematical areas (Table 4.2).

Table 4.2. Mathematics content requirements, whole survey

\begin{tabular}{|l|c|c|c|c|}
\hline \multicolumn{1}{|c|}{ Topic } & $\begin{array}{c}\text { Total } \\
\text { counts }\end{array}$ & $\begin{array}{c}\text { Overall } \\
\text { rank }\end{array}$ & $\begin{array}{c}\text { US } \\
\text { count }\end{array}$ & $\begin{array}{c}\text { US } \\
\text { rank }\end{array}$ \\
\hline Discrete mathematics & 395 & 1 & 113 & 2 \\
\hline Statistics & 374 & 2 & 133 & 1 \\
\hline Applied calculus & 318 & 3 & 98 & 3 \\
\hline Linear algebra & 288 & 4 & 53 & 5 \\
\hline Probability & 286 & 5 & 67 & 4 \\
\hline Finite mathematics & 110 & 6 & 35 & 6 \\
\hline Business mathematics & 82 & 7 & 27 & 7 \\
\hline
\end{tabular}

Among the prompted mathematics content areas, Table 4.2 compares the counts and ranking between all faculty and US faculty.
US rankings were very similar to those of all respondents, interchanging two pairs of items of adjacent rank on both lists: discrete mathematics and statistics, and linear algebra and probability. To compare responses on ranking lists of the same corresponding items, we used the Spearman's "squared differences" statistic as an index of agreement. The two lists score +0.93 on a scale of -1 (perfect disagreement, inverse rankings) to +1 (perfect agreement, identical rankings), which is a near-perfect agreement for the US and world rankings.

Both faculty and industry surveys asked: "For a strong and rigorous undergraduate degree program in information technology, indicate the areas of mathematics you believe are necessary to produce a competent IT graduate in the mid-2020s. Check all that apply" (Appendix A.1, F6 and Appendix B.1, I4). The two surveys listed slightly different response prompts: Financial Modeling was listed only in the industry survey; Business Mathematics in the faculty survey was named "Business Mathematics/Calculus" in the industry survey.

Faculty and industry rankings of the seven matched mathematics areas showed reasonable degree of agreement (Spearman's index value of +0.54 ). The top math area for both groups was Statistics, and the last area was Finite Mathematics. The areas that polarized the two groups the most were Discrete Mathematics (ranking fifth on the industry list and second on the faculty's) and business mathematics (ranking second on the industry list and sixth on the faculty list).

\subsubsection{Internship Experience}

Another question asked of faculty participants, "For the undergraduate information technology program at my institution, a credit-bearing internship experience is:", had three possible responses: Required, Optional and Not offered (Appendix A.1, F12). Table 4.3 shows the number of each response received from United States and non-United States participants, and percentages of total responses from each location.

Table 4.3. Internships in undergraduate programs

\begin{tabular}{|l|l|l|l|c|}
\hline \multicolumn{1}{|c|}{ Internships } & \multicolumn{1}{c|}{ US } & $\%$ & non-US & $\%$ \\
\hline Required & 44 & $24 \%$ & 129 & $37 \%$ \\
\hline Optional & 116 & $62 \%$ & 156 & $44 \%$ \\
\hline Subtotal Available & 160 & $86 \%$ & 285 & $81 \%$ \\
\hline Not Available & 27 & $14 \%$ & 68 & $19 \%$ \\
\hline Respondents & 187 & & 353 & \\
\hline
\end{tabular}

Credit bearing internships for undergraduates are widely available throughout the faculty surveyed group. Respondents from the United States are more apt to require the experience, when it is available, compared with respondents from the United States. From an industry perspective, the use of an internship by students who will be potential employees is always welcome. Such an experience allows a company to view first-hand the potential of a student to become an employee of the internship sponsoring organization.

\subsubsection{Technical IT Component of the Full Degree Program}

The faculty survey asked, "For the undergraduate information technology (or closely related) degree program at your institution, the technical (IT) component of the full degree program is approximately:" (Appendix A.1, F14). As possible answers, the survey offered four ranges (Table 4.4). 
Table 4.4. Technical (IT) portion of undergraduate degrees

\begin{tabular}{|l|c|c|c|c|}
\hline $\begin{array}{c}\text { "... of the } \\
\text { total program" }\end{array}$ & US & $\%$ & $\begin{array}{c}\text { non- } \\
\text { US }\end{array}$ & $\%$ \\
\hline Less than $30 \%$ & 29 & $16 \%$ & 46 & $13 \%$ \\
\hline Between $30 \%$ and $50 \%$ & 82 & $44 \%$ & 67 & $19 \%$ \\
\hline Subtotal $50 \%$ or below & 111 & $59 \%$ & 113 & $32 \%$ \\
\hline Between $50 \%$ and $65 \%$ & 51 & $27 \%$ & 128 & $36 \%$ \\
\hline Over $65 \%$ & 25 & $13 \%$ & 112 & $32 \%$ \\
\hline Respondents & 187 & & 353 & \\
\hline
\end{tabular}

540 participants answered the question. Most respondents, $86 \%$ of those surveyed, reported requiring at least $30 \%$ of a student's degree coursework to be devoted to the major subject, with little difference between the United States (16\%) and the rest of the world $(13 \%)$ in the proportion of responses reporting the lowest percentage category. However, above that lowest category, there was a dramatic contrast between the United States, where a comfortable majority of responses required $50 \%$ or less concentration on the major subject, compared with the rest of the world, where more than two-thirds of responses required more than $50 \%$ concentration.

\subsubsection{IT Knowledge Areas of Importance}

The faculty survey requested participants to "Consider the following list of knowledge areas for information technology as developed by the IT2017 Task Group. Indicate the 8 most important areas you believe will be essential or fundamental for IT graduates to know in the mid-2020s" (Appendix A.1, F13).

Table 4.5. US and non-US faculty ranking of knowledge areas

\begin{tabular}{|c|c|c|c|c|}
\hline Knowledge area & $\begin{array}{l}\text { Total } \\
\text { counts }\end{array}$ & $\begin{array}{l}\text { Overall } \\
\text { rank }\end{array}$ & $\begin{array}{c}\text { non- } \\
\text { US } \\
\text { rank }\end{array}$ & $\begin{array}{l}\text { US } \\
\text { rank }\end{array}$ \\
\hline Programming & 442 & 1 & 1 & $3-4$ \\
\hline $\begin{array}{l}\text { Web Systems } \\
\text { \&Technologies }\end{array}$ & 405 & 2 & 2 & 1 \\
\hline Networking & 367 & 3 & 6 & 2 \\
\hline Big Data & 353 & 4 & 3 & 6 \\
\hline Cloud Computing & 341 & 5 & 5 & 5 \\
\hline $\begin{array}{l}\text { Human Computer } \\
\text { Interaction }\end{array}$ & 327 & 6 & 4 & 10 \\
\hline $\begin{array}{l}\text { Information Assurance \& } \\
\text { Cybersecurity }\end{array}$ & 309 & 7 & 9 & $3-4$ \\
\hline Information Management & 275 & 8 & 7 & 8 \\
\hline $\begin{array}{l}\text { Cybersecurity: Digital } \\
\text { Forensics \& Response }\end{array}$ & 271 & 9 & 8 & 7 \\
\hline $\begin{array}{l}\text { System Integration \& } \\
\text { Architecture }\end{array}$ & 233 & 10 & 10 & 11 \\
\hline $\begin{array}{l}\text { Social \& Professional } \\
\text { Issues }\end{array}$ & 205 & 11 & 12 & 12 \\
\hline Internet of Things & 182 & 12 & 11 & 14 \\
\hline $\begin{array}{l}\text { System Administration \& } \\
\text { Maintenance }\end{array}$ & 181 & 13 & 15 & 9 \\
\hline Virtualization & 175 & 14 & 13 & 13 \\
\hline $\begin{array}{l}\text { Integrative Programming } \\
\text { Technologies }\end{array}$ & 130 & 15 & 14 & 15 \\
\hline Platform Technologies & 86 & 16 & 17 & 16 \\
\hline Green Computing & 79 & 17 & 16 & 17 \\
\hline
\end{tabular}

Table 4.5 shows the response prompts along with total counts and rank values among the 17 prompted responses from US and nonUS faculty. 540 participants responded to this survey item: 186 from the U.S. and 354 from the rest of the world. The table lists the knowledge areas in decreasing order of total counts (and overall rank values). "Cybersecurity: Digital Forensics \& Response" offers a reminder that ranking is not an average quantity. Although this item is among the top eight for both subgroups (US rank 7 and non-US rank 8), it fell lower in rank for the entire population (overall rank 9).

The Spearman's index value of +0.82 shows a reasonably high degree of agreement between US and non-US importance rankings of the 17 knowledge areas among faculty respondents. Both groups have higher degree of agreement for their respective top six areas, which include the top five areas overall. Similarly, both groups have relatively stronger agreement for their respective last nine areas, which include the last eight areas overall (ranked 10 to 17).

The industry survey asked the same question (Appendix B.1, I6) as the faculty survey (Appendix A.1, F13) about the top 8 most important knowledge areas. 541 faculty and 91 industry participants responded to this item. We note that two areas have slightly different names in the two surveys: "Cybersecurity: Digital Forensics and Response" in the faculty survey was named "Cybersecurity and Digital Forensics" in the industry survey, and "Information Assurance and Cybersecurity" in the faculty survey was named "Information Assurance and Security" in the industry survey.

Table 4.6. Industry and faculty ranking of knowledge areas

\begin{tabular}{|l|l|l|l|l|}
\hline \multirow{2}{*}{ Knowledge Areas } & \multicolumn{2}{|c|}{ Industry } & \multicolumn{2}{c|}{ Faculty } \\
\hline $\begin{array}{l}\text { Counts } \\
\text { Forensecurity and Digital }\end{array}$ & 68 & $75 \%$ & 271 & $50 \%$ \\
\hline Cloud Computing & 59 & $65 \%$ & 342 & $63 \%$ \\
\hline $\begin{array}{l}\text { Web Systems \& } \\
\text { Technologies }\end{array}$ & 58 & $64 \%$ & 405 & $75 \%$ \\
\hline Virtualization & 55 & $61 \%$ & 233 & $33 \%$ \\
\hline $\begin{array}{l}\text { System Integration \& } \\
\text { Architecture }\end{array}$ & 55 & $60 \%$ & 176 & $43 \%$ \\
\hline $\begin{array}{l}\text { Information Assurance \& } \\
\text { Security }\end{array}$ & 54 & $59 \%$ & 310 & $57 \%$ \\
\hline Information Management & 53 & $58 \%$ & 275 & $51 \%$ \\
\hline Networking & 50 & $55 \%$ & 368 & $68 \%$ \\
\hline Programming & 45 & $50 \%$ & 443 & $82 \%$ \\
\hline $\begin{array}{l}\text { Social \& Professional } \\
\text { Issues }\end{array}$ & 45 & $50 \%$ & 205 & $38 \%$ \\
\hline Big Data & 44 & $48 \%$ & 353 & $65 \%$ \\
\hline $\begin{array}{l}\text { Human Computer } \\
\text { Interaction }\end{array}$ & 41 & $45 \%$ & 328 & $61 \%$ \\
\hline Internet of Things & 34 & $37 \%$ & 182 & $34 \%$ \\
\hline $\begin{array}{l}\text { System Administration \& } \\
\text { Maintenance }\end{array}$ & 33 & $36 \%$ & 181 & $34 \%$ \\
\hline $\begin{array}{l}\text { Integrative Programming } \\
\text { Technologies }\end{array}$ & 26 & $29 \%$ & 130 & $24 \%$ \\
\hline Platform Technologies & 20 & $22 \%$ & 86 & $16 \%$ \\
\hline Green Computing & 18 & $20 \%$ & 79 & $15 \%$ \\
\hline
\end{tabular}

Table 4.6 shows the 17 knowledge areas (as named in the industry survey) with counts and percentages of respondents who selected each item in both surveys. Both surveys included a free-text "Others (please specify)" option (not shown in Table 4.6). The table lists the knowledge areas in decreasing order of preferences expressed by industry participants. Despite slight dissimilarities in 
naming two knowledge areas, the Spearman's index value of +0.52 shows a reasonable degree of agreement between industry and faculty importance rankings of the 17 knowledge areas.

\subsection{Educational Pathways}

The faculty survey asked, "Excluding first-time admission to an undergraduate program, indicate the principal source of significant external student transfers to the information technology (or closely related) program at your institution." Of the 537 faculty respondents, 186 were from U.S. institutions, representing $35 \%$ of the pool. Compared to the survey responses as a whole, there is a dramatic difference in transfers for U.S. programs: $57 \%$ of respondents indicating any transfer source are from the U.S., and $69 \%$ of respondents indicating two- and threeyear schools as the primary transfer source are from the U.S.

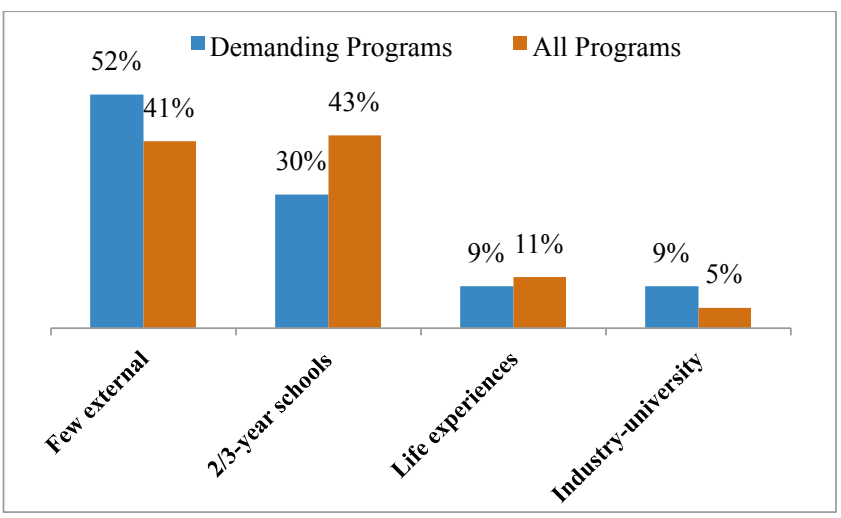

Figure 4.6. Sources of transfer students for smaller academic IT programs ( $<100$ graduates in 2014-2015)

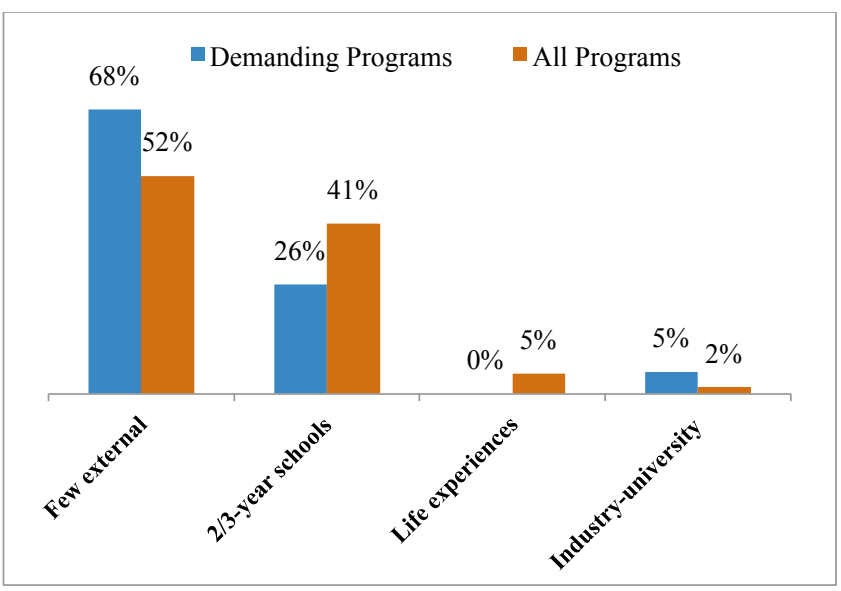

Figure 4.7. Sources of transfer students for larger academic IT programs (>300 graduates in 2014-2015)

For subsequent results, we considered a subset of the population of respondents representing "demanding" programs, where a demanding program is a program that requires some sciences beyond general education, three or more math courses, and requires more than $50 \%$ of the program is technical. According to this definition, 141 of the 589 responding programs are demanding, representing $23.9 \%$ of the institutions surveyed. See Appendix $\mathrm{C}$ for tables breaking down the faculty survey data on sources of external transfer students for demanding and all programs based on various program characteristics.
Figures 4.6 and 4.7 show the sources of transfer students for demanding programs (left bar, blue) and all programs (right bar, red) for small and large IT programs, respectively, as measured by the number of graduates in the 2014-2015 academic year. As compared with all schools, more of the demanding programs of any school size report few external transfer students. Fewer demanding programs report transfers from 2-year and 3-year schools, and more report industry-university articulation as their primary source of transfers, as compared with all programs. As compared with smaller programs ( $<100$ graduates in 2014-2015), more of the larger programs ( $>300$ graduates) report few external transfers.

Table 4.7. Sources of transfer students for academic IT programs with $<\mathbf{3 0 \%}$ technical content

\begin{tabular}{|l|l|l|}
\hline \multicolumn{1}{|c|}{ Sources of transfer students } & $\begin{array}{c}\text { All } \\
\text { Programs }\end{array}$ & $\begin{array}{c}\text { Demanding } \\
\text { Programs }\end{array}$ \\
\hline Few external & $44 \%$ & $0 \%$ \\
\hline 2/3-year schools & $41 \%$ & $0 \%$ \\
\hline Life experiences & $13 \%$ & $0 \%$ \\
\hline Industry-university articulation & $2 \%$ & $0 \%$ \\
\hline
\end{tabular}

Table 4.8. Sources of transfer students for academic IT programs with $30 \%-50 \%$ technical content

\begin{tabular}{|l|c|c|}
\hline \multicolumn{1}{|c|}{ Sources of transfer students } & $\begin{array}{c}\text { All } \\
\text { Programs }\end{array}$ & $\begin{array}{c}\text { Demanding } \\
\text { Programs }\end{array}$ \\
\hline Few external & $35 \%$ & $0 \%$ \\
\hline 2/3-year schools & $52 \%$ & $0 \%$ \\
\hline Life experiences & $8 \%$ & $0 \%$ \\
\hline Industry-university articulation & $5 \%$ & $0 \%$ \\
\hline
\end{tabular}

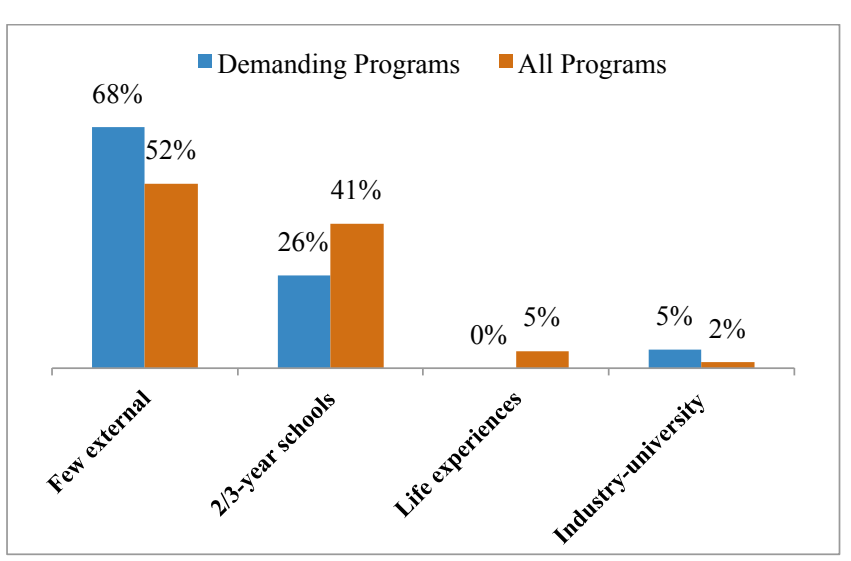

Figure 4.8. Sources of transfer students for academic IT programs with $50 \%-65 \%$ technical content

Among programs that have a significant source of transfers into the program, two- and three-year schools were the most reported primary source. Tables 4.7 and 4.8 , and Figure 4.8 show the sources of transfer students for demanding programs and all programs broken down by the percentage of technical content in the program. By definition the demanding programs have over $50 \%$ technical IT content, so they do not appear in Tables 4.7 and 4.8 which show transfers sources for programs with $<30 \%$ and $30-50 \%$ technical content, respectively.

For the most technical programs $(>65 \%$, Figure 4.9$)$, we find a greater percentage of respondents report few external transfer 
students. Two- and three-year schools are still the primary source of transfers for the highly technical programs that report transfers, although industry-university articulation has greater representation than in less technical programs.

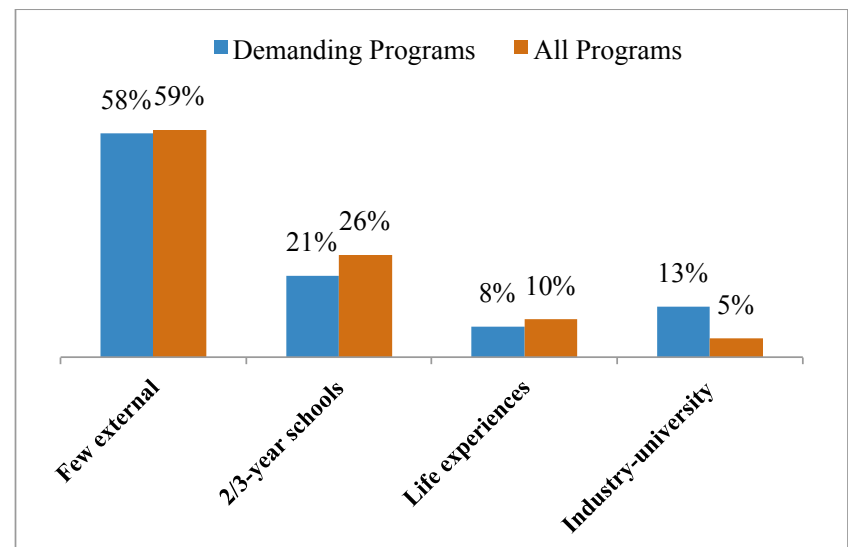

Figure 4.9. Sources of transfer students for academic IT programs with $>65 \%$ technical content

\subsection{Future of IT}

We now present results of investigations on the future of IT. As before, these results reflect areas of indicators and surveys, predictors, and information related to IT departments. We now describe these results.

\subsubsection{Indicators and Surveys}

The results of the IT professionals industry survey (Appendix B Industry Survey Results) show that out of 93 responses (almost all from the United States), project management was by far the number-one skill required with $78.0 \%$ of the respondents indicating that skill. The next most important skill was information (cyber) securing with $73.6 \%$ of the respondents favoring that skill. The next four important skills expected for the mid-2020s were soft skills, business analytics, database administration and architecture, and data analytics, with responses of $64.8 \%, 59.3 \%, 51.6 \%$, and $49.5 \%$, respectively. Only six respondents suggested topics other than those mentioned above. These include business process management, application management, IT infrastructure and architecture/design, web systems and technologies, writing, analytical thinking, and regulatory compliance.

Cloud computing is a technology which combines the internet, web browsers and rich applications in one. To provide a cloudbased service, a provider uses cluster of servers to offload processing or storage for a user [57]. The working group used the IT2017 industry survey and a web search to ascertain the importance of cloud computing in the mid-2020s. The outcome was enlightening. Both the industry survey and the web search revealed similar results, namely, that cloud computing is not on the radar for the future. In fact, the industry survey rated cloud computing with only $42.9 \%$ favorability. Industry seems not interested in the future of the cloud as a promising investment. The "2013 Future of Cloud Computing - 3rd Annual Survey Results" painted a soft picture on what was once a promising area of technology. A fact-based story that disrupted conventional wisdom forced a major consulting firm ${ }^{5}$ that it should not jump on

\footnotetext{
5 http://www.dworin.com/north-bridge-venture-partners-and-thefuture-of-cloud-computing/
}

the cloud bandwagon. The Wall Street Journal published an article in 2014 titled, "Forget 'the Cloud'; 'the Fog' Is Tech's Future" there provides further evidence that the cloud will not be a dominant skill in the future of information technology [49].

\subsubsection{Predictors}

The analysis attempts to describe how IT predictions often turn out to be 'wrong', it appears there is no obvious decline in the number of predictions made, the appetite for this kind of knowledge, or the standing of those producing this kind of insight. The authors discussed the main question of the section: What are the main predictors? The survey results indicated the top five skills sets selected; we then researched them as the main predictors for 2025: 1) project management; 2) cybersecurity; 3) soft skills; 4) business analysis; 5) database admin and architecture/ data analytics.

\subsubsection{Project Management}

We can define project management or IT project management as a process of planning, organizing and delineating responsibility for the completion of an organizations' specific IT goals ${ }^{6}$. Additionally, IT is the use of any computers, storage, networking and other physical devices, infrastructure and processes to create, process, store, secure and exchange all forms of electronic data.

Phillips describes an IT as especially slippery because it is always moving, changing, adapting and challenging business, as we know it [55]. IT project management is further complicated by shifting business needs and demanding stakeholders. Because good IT project management is difficult to execute, a CIO has put together this guide to understanding IT project management that includes an overview of what is required for successful project management as well as additional technology resources to learn more about it.

An IT project is any information technology project that has an assigned start and end date, often with specific milestones and goals to meet during the development cycle. These are temporary, short-term efforts to create a unique product, service or environment such as removing old servers, developing a custom ecommerce site, creating new desktop images or merging databases. Phillips (2014) presents IT projects that are constrained by three factors: time, cost and scope. For a project to be successful, these three constraints (often called the Triple Constraints of Project Management) must be in equilibrium. If any constraint is out of balance, the project is headed for disaster. All projects, IT or otherwise, move through five phases in the project management lifecycle, i.e. Initiating; Planning; Executing; Monitoring and controlling; Closing. Each phase contains processes that move the project from idea to implementation.

\subsubsection{Cybersecurity}

The increasing dependence on information and communication technologies (ICT), especially the internet and internet services, is one of the biggest challenges for cyber security. Cybersecurity has complex issues affecting many application domains and straddling many disciplines and fields. Securing the critical infrastructures requires protecting not only the physical systems, but also the cyber portions of the systems on which they rely. The most significant cyber threats are fundamentally different from those posed by the "script kiddies" or virus writers who traditionally have plagued users of the internet.

\footnotetext{
${ }^{6}$ http://searchcio.techtarget.com/
} 


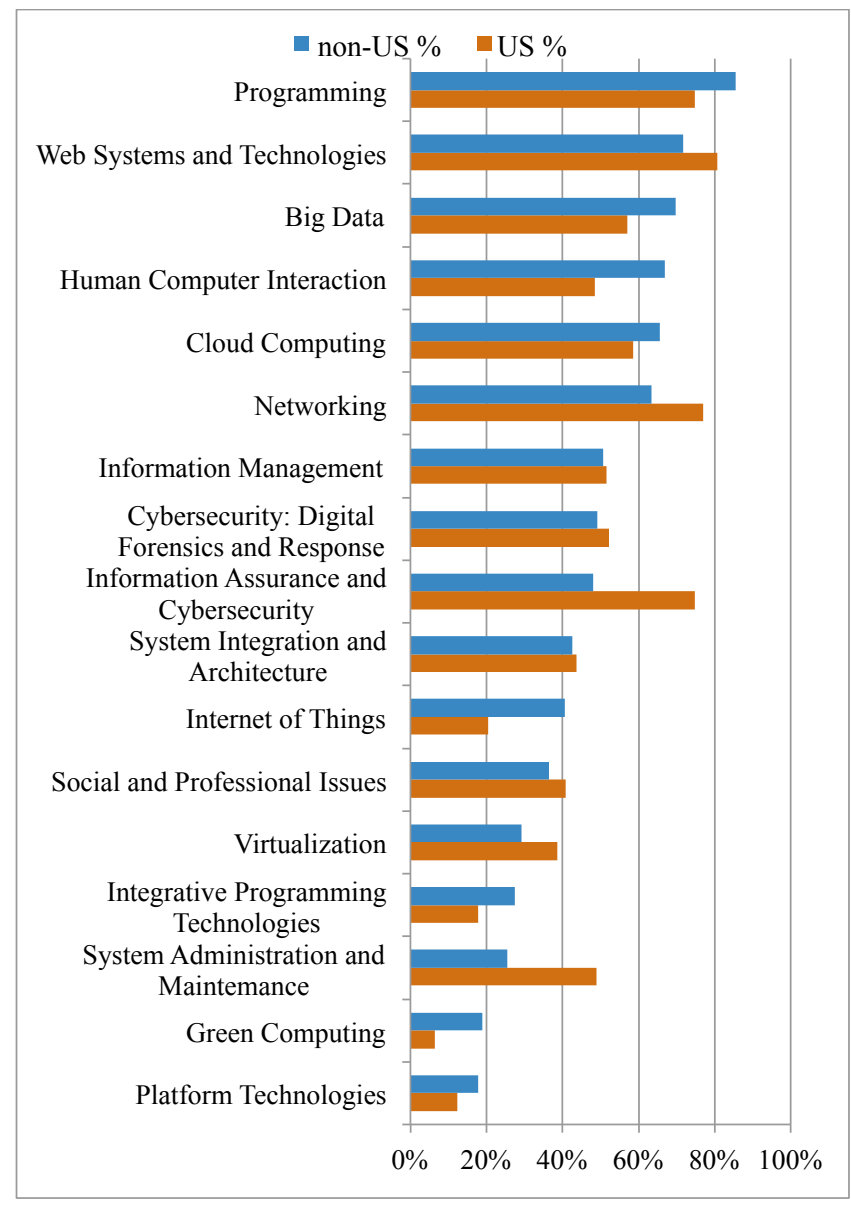

Figure 5.1. Comparison of US and non-US faculty ranking of knowledge areas

\subsubsection{Soft Skills}

Some universities are attempting to address the need for soft skills as part of what is termed user advocacy. They are working with students to make them realize the importance of interpersonal skills in their future career. As we have learned in the 2008 Model Curriculum [40, 41], communications, teamwork and ethics are necessary skills for IT career success. Making students realize that they need to incorporate these skill sets in their relationships with users and team members is crucial to a student's complete education. Educators have a responsibility to their students to make them realize that technical education alone will not help them in gaining a job - they must learn to become part of a team and put themselves in the place of the user and their fellow team members. IT professionals should not be isolated in their areas of expertise, they must have the ability to work with different constituencies within the enterprise, effectively communicate their ideas, possess project management skills and give successful presentations.

\subsubsection{Business Analysis}

The fourth skill indicated by industry as important for the future is business analysis, defined as "Business analysis is the set of tasks and techniques used to work as a liaison among stakeholders in order to understand the structure, policies, and operations of an organization, and to recommend solutions that enable the organization to achieve its goals. Business analysis involves understanding how organizations function to accomplish their purposes, and defining the capabilities an organization requires to provide products and services to external stakeholders. It includes the definition of organizational goals, how those goals connect to specific objectives, determining the courses of action that an organization has to undertake to achieve those goals and objectives, and defining how the various organizational units and stakeholders within and outside of that organization interact" [29].

Hand in hand with project management, business analysis is an integral step in the complete life cycle of a project - providing important analysis as well as monitoring and controlling a project's variables.

\subsubsection{Data Administration/Big data}

Gartner Research ${ }^{7}$ shows that companies capture trillions of bytes of information about their customers, suppliers, and operations, and they embed millions of networked sensors in the physical world in devices such as mobile phones and automobiles, sensing, creating, and communicating data. Multimedia and individuals with smartphones and on social network sites will continue to fuel exponential growth. Big data-large pools of data captured, communicated, aggregated, stored, and analyzed - are now part of every sector and function of the global economy.

Although the formulation of problems in processing big data in different subject areas differs, there may be common approaches to the technologies for their processing. They base these approaches on proven toolsets, which may require some adjustment or adaptation in each case. The IT specialist in the processing of big data must resolve these problems (e.g., through extensive use of MapReduce, Hadoop, time-series analyses, and/or future data-mining techniques).

\section{DISCUSSION}

\subsection{IT Curriculum Perspectives}

\subsubsection{U.S. and non-U.S. Faculty Comparison}

US and non-US faculty groups had in common seven of their top eight most important knowledge areas: Programming, Web Systems and Technologies, Networking, Big Data, Cloud Computing, Information Management, and Cybersecurity: Digital Forensics and Response (Figure 5.1)

Among the top eight areas with overall rank 1 to 8 (Table 4.5), the largest difference of support between the US and non-US faculty groups was for Human Computer Interaction and Information Assurance \& Cybersecurity knowledge areas. The occurrence of the word "cybersecurity" in two knowledge areas, "Information Assurance and Cybersecurity" and "Cybersecurity: Digital Forensics and Response" might explain the difference. US faculty selected both these areas among their top seven areas. Non-US faculty voted for one of them, "Cybersecurity: Digital Forensics and Response" and made room for "Human Computer Interaction" among their top four preferences.

\subsubsection{Faculty and Industry Comparison}

Faculty and industry groups had six areas with $50 \%$ or more support from their respondents: Cybersecurity and Digital Forensics, Web Systems and Technologies, Information Assurance and Security, Information Management, Networking, and Programming (Figure 5.2). Among these six areas with majority support from both groups, "Programming" and "Cybersecurity and Digital Forensics" have the most polarized

\footnotetext{
${ }^{7}$ http://www.gartner.com/technology/topics/big-data.jsp
} 
support. The two groups' most pronounced disagreement was for two areas with majority support only from industry: "System Integration and Architecture" and "Virtualization"; and two areas with faculty-only majority support: "Big Data" and "Human Computer Interaction".

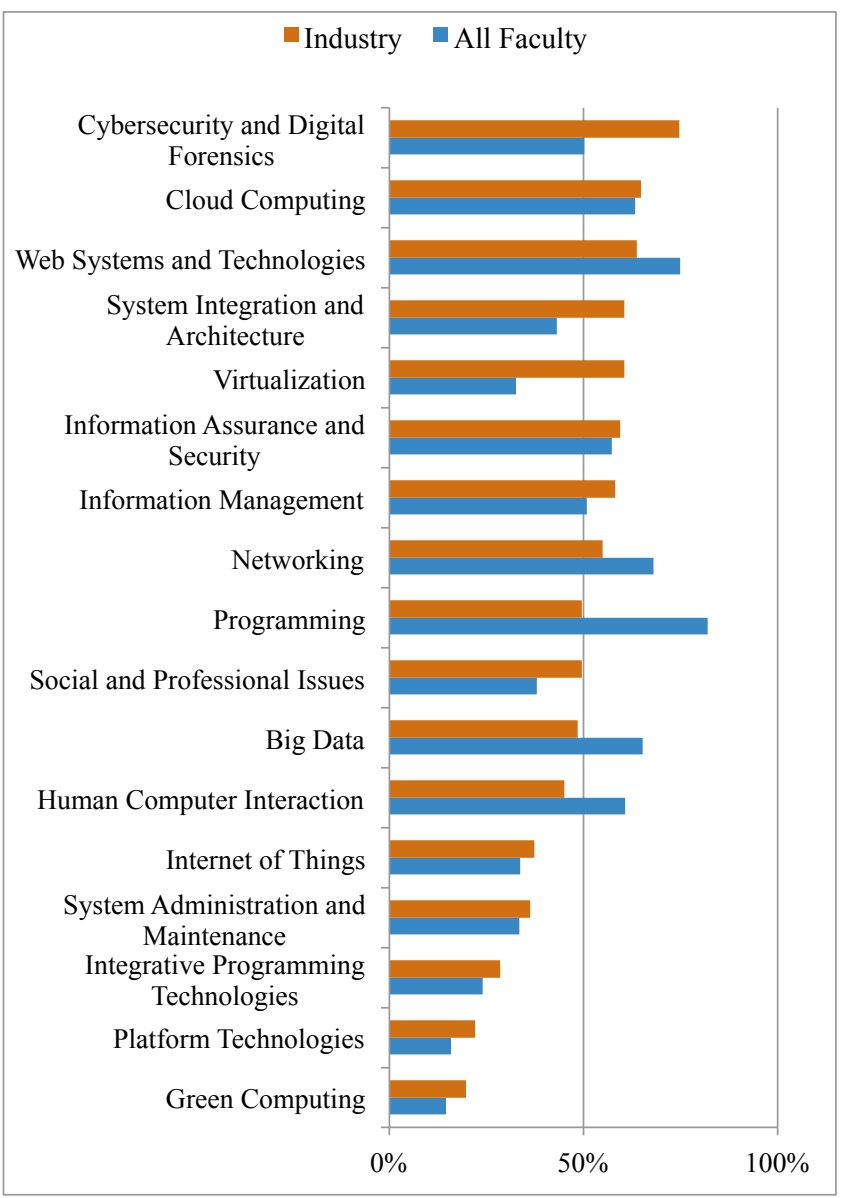

Figure 5.2. Comparison of industry and faculty ranking of knowledge areas

\subsection{Educational Pathway Comparisons}

From the survey results presented, we note that significantly more U.S. IT programs take transfer students (from any source) compared with the population of all programs. Furthermore, when it comes to the mechanism of transfer, significantly more U.S. IT programs selected 2-year and 3-year schools as the primary transfer source.

\subsubsection{U.S. Educational Pathways}

The traditional pathway into any college degree program is entry after high school, though the preparation and requirements for college entry may vary from country to country. In the United States, there is a growing emphasis on computing education throughout a child's K-12 experience, with the prospect of leading to more students choosing computing as a career. As noted in the ACM pathways report [39], computing jobs are among the fastest growing areas of employment in the U.S., and access to computer science for K-12 students needs to be expanded. One organization helping to meet the challenge is Code.org, whose vision is that "every student in every school should have the opportunity to learn computer science" [13]. While some of these efforts focus on computer science, at least in name, the efforts are relevant to computing in general. In a comprehensive study focusing on the state of Georgia, Guzdial et al. [26] examined how computing experiences in middle and high school influenced students choices to pursue computing in college.

Beyond the traditional high school-to-college path [21], it is important to consider other entry-points or pathways into an IT degree. These include transfer from two-year or three-year technical schools or community colleges; transfer into IT from another major; transfers from industry-university articulation agreements; returning to school from industry, for example to change careers; and transfers due to other life experiences.

It should also be noted that educational pathways into and through IT may not include a traditional bachelor's degree IT program at all. Students can obtain associate degrees in IT from community colleges or technical schools, or certificates from professional code schools or training companies. Some students pursue selfstudy or use online resources or MOOCs to teach themselves IT, and may obtain industry certifications to demonstrate their skills.

\subsubsection{Australian Educational Pathways}

In Australia, the majority of students enter universities directly after their successful completion of high school with a national tertiary entrance ranking (NTER) score. If their NTER score is not high enough, and they know they wish to study IT, they may undertake TAFE qualifications, such as Certificate II, III and IV in IT, which then lead into the second or third year of the IT degree. However, there are people who do not wish to enter university straight from school, and may take a couple of years working in industry, or travelling and then come back as mature age students. Depending on their industry work, these students may receive recognition of prior learning (rpl) and simply take the remaining courses to complete their program. Finally, there are students who select other programs, typically Software Engineering or Computer Science, and may not do well and transfer across to the IT Program. These students are typically those who have very diverse backgrounds, possibly international students, who require a successful outcome for their degree program, regardless of the discipline.

Literature about pathways and success or otherwise is available on the Office of Learning and Teaching (OLT) website [52] where many federally funded projects have been undertaken. In one project report, McLaughlin et al summarize by stating that, "Higher education must become more accessible, flexible and equitable to underrepresented groups. Increasing the diversity of the student cohort is ... central to ensuring individual, community and social well-being" [47]. In another final project report, Partridge et al. [54] report that educators have acknowledged the importance of designing approaches to education that are responsive to the rapid and ongoing technological change of the evolving information age and developing dynamic curricula that accommodate the demands of an increasingly broad and diverse employment landscape. Continuing, "Change has been recognized as critical for meeting current and future needs for employment in the profession and for providing a diverse supply of graduates with the attributes required for information work in the rapidly changing twenty-first century". For managing such rapid change, it is essential to consider student and tertiary education considerations, as well as industry workforce planning and future employability [27].

In Australia, many pathways and programs in IT exist, ranging from publicly funded TAFE (Tertiary and Further Education) 
Colleges to polytechnics to universities that provide IT degree programs. There are also many private providers of IT such as http://www.it-pathways.com/ and several online providers. Open Universities Australia (OUA) offers IT programs and many universities offer online courses into OUA as well as providing their own online courses and programs and many combinations of blended learning to deliver their IT programs.

\subsubsection{Educational Pathways in China}

The development of IT-related undergraduate education has been a boom in China. Integrating the analysis and ideas of ACM-IEEE in the CC2005 document $[11,63]$, the Ministry of Education has encouraged universities to develop a variety of directions under the name "Computer Science and Technology". A new pyramid model of computing education was developed that identified three basic directions for training the nation's high tech workforce: science-oriented (computer science), engineering-oriented (computer engineering and software engineering) and technologyoriented (information technology), with the smallest talent pool at the top, and the largest talent pool at the bottom [65]. By the end of 2012, China had doubled the number of colleges and universities to 2,409, most of which have established their own IT institutions [59]. As a result, the IT major has become the most popular major in terms of total enrollment. For example, in the year of 2010, the total enrollment for all engineering majors was 1.172 million; IT majors alone accounted for as high as $28 \%$ [66].

Another special pathway provided by IT training companies exists. The Ministry of Information Industry, now renamed as the "Ministry of Industry and Information Technology" (MIIT), launched the "national information technology talent cultivation project" in 2004. It aimed to optimize integration degree education, professional qualification, technical level and high and new technical training, and other various kinds of education training resources. It did this through the guidance of industry, government, to promote the socialization of education and training by opening up a new way of education and training. IT personnel innovation ability construction, reform the contents, methods and mechanisms of education training, deepening the reform of the management system of the IT talent, cultivate a large number of in-line with the industry development needs the innovative talents. The Education and Test Center of MIIT is responsible for the specific certification issues. There are more than 70 organizations and nearly 200 exam training bases, training about 700,000-1,000,000 IT professionals each year [48]. This is a very important IT talent resource.

\subsubsection{Canadian Educational Pathways}

In Canada the traditional high school pathway into university or college IT, computer science, MIS programs is still the most popular path, with approximately 58,000 students enrolled in these programs each year and with approximately 13,000 graduates. This indicates many students are taking classes either supplementing current knowledge and not necessarily to complete a diploma or university program. Only a relatively small percent of post-secondary students is specific to IT and the computing sciences. The total number of post-secondary students enrolled in the 2012/13 school year in Canada 2.023,191; (i.e., college enrollment 739,959 ; university enrollment $1,283,229$ ) [61]. In the area of mathematics, computer and information sciences programs, 58,230 students enrolled (i.e., college enrollment 19734; university enrollment 38,493). Total graduates were 13,092 in the area of mathematics, computer and information sciences programs (i.e., college graduates 5787; university graduates 7308).
Today, more arrangements that are cooperative are occurring each year between university four-year IT programs and college twoyear IT programs for transfer credits from the two-year diploma programs to the four-year university programs. In addition, there are now many 'university colleges' that are accredited to provide degrees, with approval from the accreditation body, Universities Canada (formerly The Association of Colleges and Universities in Canada, AUCC) [53]. IT and computer science program accreditation is handled by the Accreditation Council of CIPS, Canada's Association of IT Professionals [9].

An advisory committee made up of industry leaders from the region the institution serves guides most IT programs. For generalist positions such as IT support technician some institutions look to Canada's Information and Communications Technology Council's competency profiles to guide curriculum development. Others rely on their advisory committees and the experience and knowledge of their faculty. Current technical skills are only one part of a good IT graduate and institutions refer to organizations like the Canadian Information Processing Society (CIPS) and their body of knowledge and professionalism and ethics materials to inform the balance of a program's outcomes. Many also collaborate with their business programs to provide the critical business knowledge seen by some as a requirement for all IT workers. "We estimate that by 2016 approximately 106,000 ICT jobs will need to be filled in Canada with demand for critical jobs far exceeding the supply. This figure will be further compounded if we account for the new emerging ICT sectors" [2].

\subsection{Future of IT}

\subsubsection{Surveys and Indicators}

The data from the industry survey indicate clearly that project management, cybersecurity, and soft skills are among the top skills needed in the next decade. These skills are also important today where project management is an expected talent in the IT industry and where industry expects cybercrime losses to exceed $\$ 120$ billion USD by 2017 [16]. Industry considers soft skills to be equally as important as technical skills when making hiring decisions.

What do we consider soft skills? They are "desirable qualities for certain forms of employment that do not depend on acquired knowledge: they include common sense, the ability to deal with people, and a positive flexible attitude" [19]. When hiring either IT graduates or experienced IT professionals, employers will often choose a candidate with excellent interpersonal skills who lacks certain technical skill sets over a more technically strong person lacking soft skills. They find they can easily train them in these technical skills in a seminar or on the job. People normally learn interpersonal skills away from a classroom; it is part of one's upbringing or interacting in social situations.

The new strategy for the internet of things (IoT) supporting the development of the most dynamic and agile IoT ecosystem and industry in the world, could really transform people's lives, drive growth, create employment and address societal challenges [35]. According to estimates, nearly five billion things will interconnect by 2015 , reaching 25 billion by 2020 , helping users save energy, reduce traffic jams, increase comfort, and get better healthcare and increased independence. IoT will not only allow companies to change their traditional business models through new services, but will also help combine the benefits of selling products with valueadded digital service. According to the strategy there are selected current prominent areas of the internet of things: research cluster; 
innovation ecosystems; IoT standardization; policy issues (trust, security, liability, privacy); smart living environments for ageing well (e.g., smart house); smart farming and food security; wearables; smart cities; smart mobility (smart transport/smart vehicles/connected cars); smart environment (smart water management); smart manufacturing [35].

We expect the cloud to be a standard fixture for the mid-2020s. Cloud computing is a technology that combines the internet, web browsers, and rich applications into one. The National Institute of Standards and Technology in the United States suggests that "cloud computing is a model for enabling convenient, on-demand network access to a shared pool of configurable resources (e.g. networks, servers, storage, applications and services) that can rapidly be provisioned and released with minimal management effort or service provider interaction [50]. To a cloud-based service, a provider uses a cluster of servers to offload processing provide or storage for a user. The future of the cloud is more interesting than discussing its current merits and failures. With each development, there will be cloud companies that will develop a distinct segment. According to Dinh et al. [20], a flood of IT innovations such as data center virtualization, optimization and automation, while greatly beneficial, have also brought diverse solutions and physical and virtual challenges to today's data center infrastructure.

The best response to these new challenges is effective IT management. Effective IT management requires a vendorindependent platform and centralized data center management capability. Enterprise Management Associates (EMA) explores a pragmatic view of data center management in order to deliver the best practices in real-world data centers for overarching management solutions. This will enable interoperability of managed entities across physical and virtual boundaries and help IT to control costs and manage diverse, complex technology environments while achieving core objectives for availability and security. Mims presents the idea of forgetting 'the Cloud'; 'the Fog' is tech's future. He also declares that cloud advocates are fond of declaring that $100 \%$ of computing will someday reside in the cloud. Getting data into and out of the cloud is harder than most engineers (or at least their managers) often are willing to admit. The problem is bandwidth. If you are a company simply seeking to save the cost and headache of storing data yourself, the cloud is great as long as all you need to do is transfer data back and forth via high-speed wiring [49].

\subsubsection{Information Resources}

The issue is that there are too many sources of information. It will be a challenge to weed through irrelevant information and hype to distinguish true industry trends. Determining which is hype and which is not, should rely on the persistence of an emerging or disruptive technology; the number of years it persists will determine if it truly should be incorporated into the curricula development processes. In a way, the speed at which the curricula development takes will lend itself to this filtering process. In addition, the research that supports the insertion of new knowledge areas will rely on materials spanning multiple years that in itself then will ignore short-term hype or buzz phrases.

The length of time in existence and sustainability within the IT industry can also filter IT practitioner (member) organizations. These practitioner associations publish survey results, white papers, position papers and often-monthly journals, newsletters and internal publications that are a vast resource for materials. The Federation of Enterprise Architecture Professional
Organizations (FEAPO) lists some such long-lived organizations (Appendix D).

Current conference proceedings and outcome documents are a great resource for current industry directions and trends. In this category, worldwide organizations will provide a perspective that professionals should watch closely. Organizations connected to the UN have a unique perspective since rather than having specific countries interests in mind, they have the global interests in mind. Table 5.1 shows some examples of such proceedings. Obviously, books are still a resource that we should not overlook. Some examples of books that discuss and provide opinion and research for the future of IT include "Second Machine Age: Work, Progress and Prosperity in a Time of Brilliant Technologies" [6] and "The Shift: The Future work is already here" [24].

Table 5.1 Examples of UN-related organizations

\begin{tabular}{|c|c|}
\hline $\begin{array}{l}\text { WCC 2015, Opening } \\
\text { our Future Together }\end{array}$ & http://www.wcc-2015.org/ \\
\hline $\begin{array}{l}\text { World Summit on the } \\
\text { Information Society }\end{array}$ & $\begin{array}{c}\text { http://groups.itu.int/wsis- } \\
\text { forum2012/Highlights/OutcomeDocument.as } \\
\text { px } \\
\text { http://www.itu.int/net4/wsis/forum/2015/ }\end{array}$ \\
\hline UN Sustainable Goals & $\begin{array}{l}\text { https://sustainabledevelopment.un.org/focuss } \\
\text { dgs.html }\end{array}$ \\
\hline $\begin{array}{c}\text { 38th International } \\
\text { Conference on Software } \\
\text { Engineering }\end{array}$ & http://2016.icse.cs.txstate.edu/ \\
\hline
\end{tabular}

Educational program delivery (i.e., secondary, post-secondary and graduate) is also an obvious source of material to follow the changes occurring in the IT industry. Most programs have regular input from industry advisory committee or boards to ensure they align with industry needs. Moreover, many accreditation bodies exist which again regularly evaluate education program content and delivery (i.e., learning outcomes). Also in this similar area there is professional development delivery (post-academic, noncredit programs) specific to an industry or IT domain that often fill gaps for emerging areas of specialization the industry is looking for. It is not feasible to list the plethora of programs available today; one could be easily research them to determine trends occurring in the IT domain.

Another source that again is not reasonable to list here is the technology vendor conferences, tradeshows and expos. Vendor presentations are often aimed and discussing innovations and new products providing an endless supply of information. 
Table 5.2. Examples of IT-related websites

\begin{tabular}{|c|c|}
\hline Forbes & http://www.forbes.com/ \\
\hline Forrester & https://www.forrester.com/home/ \\
\hline Facebook & https://www.facebook.com/OpenAcademyProgram \\
\hline Gartner & http://www.gartner.com/technology/home.jsp \\
\hline IT World & http://www.itworldcanada.com/ \\
\hline LinkedIn & https://www.linkedin.com/ \\
\hline Twitter & $\begin{array}{c}\text { https://twitter.com } / \text { search?q }=\text { TechnologyReview\&src }=\mathrm{t} \\
\text { yah }\end{array}$ \\
\hline $\begin{array}{l}\text { Australia's } \\
\text { skills } \\
\text { shortage } \\
\text { reports }\end{array}$ & $\begin{array}{l}\text { http://www.businessinsider.com.au/australia-needs- } \\
\text { another-100000-tech-workers-as-the-economy-is-hit- } \\
\text { with-another-wave-of-digital-disruption-2015-6 } \\
\text { http://www.hcamag.com/hr-news/popular-culture--the- } \\
\text { root-of-australias-serious-skills-shortage-201687.aspx }\end{array}$ \\
\hline $\begin{array}{c}\text { Canadian } \\
\text { Market } \\
\text { Outlook }\end{array}$ & $\begin{array}{l}\text { http://www.digcompass.ca/labour-market-outlook- } \\
\text { 2015-2019foward/ }\end{array}$ \\
\hline
\end{tabular}

Table 5.2 shows examples of general news articles and posts on the multitude of websites now available related to IT.

\section{SUMMARY}

Based on the research findings, the working group has arrived at the several conclusions. With regard to the meaning of IT, the research shows that many meanings of IT exist depending on academia, industry, geographic location. Additionally, the content of an academic degree in a particular country often reflects the needs of the industry in that area. Indeed, information technology is a communication and information platform that is ubiquitous that moved from the techies to the masses. Therefore, it is important to prepare IT students to work with diverse applications and professions because IT is an enabler; it promises to generate greater growth in the future.

With respect to curricular IT frameworks, there is agreement between industry and academia on science requirements and highly close agreement on math requirements. Statistics is a top subject choice for math that is necessary in all IT degree programs. Knowledge areas of importance showed various agreements and disagreements, but overall the data show a general positive agreement. The structure of IT programs varies by type of institution and geographic location. There were significant differences between US and non-US IT degree programs regarding the IT technical component, where non-US IT programs were more robust in their technical components that provided a normal pathway to graduate study. The top knowledge areas for which industry and academia reached agreement were cybersecurity and information management.

Regarding IT pathways to a bachelor's degree in IT, the research showed that US IT programs provided more transfers from many sources, but even more transfers occurred from two-year and three-year technical programs. We found that demand, IT intensity, and program size correlate differently with participation of transfers. In non-US countries, transfers to baccalaureate programs were few due to very limited pathways and conformity to local regulations.

The future of IT remains fluid as expected. Notwithstanding, it was intensely clear from the research that soft (people) skills are as important as technical skills and that project management is an important professional skill. IT university enrollments must keep up with job demands as the IT industry changes. When designing undergraduate programs, universities would be wise to consider curricular IT reports from professional organizations and use predictor data from IT trackers such as Forbes and Gartner organizations so their programs are as futuristic as possible in an ever-changing IT world.

\section{ACKNOWLEDGEMENTS}

We would like to acknowledge Prof. Hajime Ohiwa, Keio University, Japan, and Luis Ayala, Universidad Francisco Marraquin, Guatemala, for their insights shared with the working group. Our thanks go to Paul Snow, who has tirelessly supported this study with statistical analysis work. We also thank ACM and AITP for their support with the two surveys.

\section{REFERENCES}

[1] Information Technology Studies. 2014. Helsinki Metropolia of Applied Sciences.

http://www.metropolia.fi/en/apply/studies-bachelortechnology/information-technology/ Accessed 2015 Jul 06.

[2] Anani N. 2012. Fixing the Skills Gap and Understanding the Labour Shortages (April 2012). Standing Committee on Human Resources, Skills, and Social Development and Status of Persons with Disabilities. http://www.ictcctic.ca/wpcontent/uploads/2012/06/ICTC_HUMAPresentation_EN_0412.pdf. Accessed $2015 \mathrm{Jul} 06$.

[3] Brazilian Association for Information and Communications Technology. 2014. Associations unite "For a Digital and Competitive Brazil" (August 20114).

http://www.brasscom.com.br/brasscom/Ingles/detNoticia.php ? codArea $=2 \& \operatorname{codCategoria}=54 \& \operatorname{codNoticia}=794$. Accessed 2015 Jul 05.

[4] Basic knowledge of basic information technology's test; http://skill-style.com/license/johoshori-it/IT-zenpan/kihonjyoho-gijutsusha.html. Accessed $2015 \mathrm{Jul} 05$.

[5] Bowen, N. and Spohrer, J. 2010. Viewpoint: the future of computing practice and education. Computer, 43, 3, 86-89.

[6] Brynjolfsson, E. and McAfee, A. 2014. The Second Machine Age: Work, Progress and Prosperity in a Time of Brilliant Technologies $\left(1^{\text {st }}\right.$ ed.). W.W. Norton \& Company, New York, NY.

[7] Employment Projections: Employment by detailed occupation. 2015 Bureau of Labor Statistics (December 2015). http://www.bls.gov/emp/ep_table_102.htm. Accessed 2015 Jul 04.

[8] Calitz A., Greyling J., and Cullen M. 2011. ICT career track awareness amongst ICT graduates. In Proceedings of the South African Institute of Computer Scientists and Information Technologists Conference on Knowledge, Innovation and Leadership in a Diverse, Multidisciplinary Environment (SAICST'11). ACM, New York, NY, USA, 5968. DOI=http://dx.doi.org/10.1145/2072221.2072229. 
[9] Accreditation Criteria and Policies. Canada's Association of Information Technology Professionals.

http://www.cips.ca/node/2222. Accessed 2015 Jul 04.

[10] Mexico is an Information Technology Powerhouse. 2011. The Catalyst (October 2011). http://thecatalist.org/2011/10/mexico-is-an-informationtechnology-powerhouse/; Accessed 2015 Jul 04.

[11] Computing Curricula 2005: The Overview Report. Joint Task Force for Computing Curricula 2005 (September 2005). http://www.acm.org/education/education/curric_vols/CC200 5-March06Final.pdf. Accessed 2015 Jul 08.

[12] Annual IT Report in the Kingdom of Saudi Arabia. 2015. Communications and Information Technology Commission. http://www.citc.gov.sa/english/Reportsandstudies/Reports/Pa ges/IT-Report.aspx. Accessed 2015 Jul 05.

[13] Code.org. 2015 http://code.org. Accessed 2015 Jul 4.

[14] College of Computer and Information Sciences. 2015. King Saudi University. http://ccis.ksu.edu.sa/en. Accessed 2015 Jul 04.

[15] Cooper, S., Grover, S., M., Guzdial M., and Simon, B.. A Future for Computing Education Research. Communications of the ACM, 57, 11 (October 2014), 34-36. DOI=http://dx.doi.org/10.1145/2668899.

[16] Cybercrime Statistics and Trends (Infographic). 2013. GOGulf (December 2013). http://www.go-gulf.com/blog/cybercrime/. Accessed 2015 Jul 05.

[17] Daintith J., ed. 2009. A Dictionary of Physics (6 ${ }^{\text {th }}$ ed.). Oxford University Press.

[18] Specialties and fields of study. 2015. Saint Petersburg State University.

http://www.apmath.spbu.ru/en/education/speciality/ Accessed 2015 Jul 05.

[19] Soft skills (n.d.) Collins English Dictionary - Complete and Unabridged. http://www.thefreedictionary.com/soft+skills. Accessed 2015 Jul 05.

[20] Dinh, H.T., Lee, C., Niyato, C., and Wang, P. 2013. A Survey of Mobile Cloud Computing: Architecture, Applications, and Approaches. Wireless Communications and Mobile Computing. John Wiley \& Sons, 13, 18 (December 2013), 1587-1611. doi:10.1002/wcm.1203.

[21] Diploma to degree pathways. 2015. Seneca College. http://www.senecacollege.ca/degreetransfer/guide/Diplomato-Degree-Pathways.pdf. Accessed 2015 Jul 06.

[22] Ekstrom J. and Lunt B. Academic IT and adjacent disciplines. In Proceedings of the 2010 ACM conference on Information technology education (SIGITE'10). ACM, New York, NY, USA, 1-8.

DOI=http://dx.doi.org/10.1145/1867651.1867653.

[23] Germany, a world leader in technology, engineering and innovation, 2012. Digital Agenda for Europe - A Europe 2020 Initiative (September 2012).

http://ec.europa.eu/digital-agenda/en/news/germany-worldleader-technology-engineering-and-innovation. Accessed 2015 Jul 04.

[24] Gratton, L. 2011. The Shift: The future work is already here. Collins, London.

[25] Government program "Informational Kazakhstan - 2020". 2015. The United Nations specialized agency for Information and Communication Technologies (ITU).

http://www.itu.int/net4/wsis/stocktaking/projects/Project/Det ails?projectId=1383212842. Accessed 2015 JUL 05.

[26] Guzdial, M., Ericson, B., McKlin, T., and Engelman, S. A statewide survey on computing education pathways and influences: factors in broadening participation in computing. In Proceedings of the ninth annual international conference on International computing education research (ICER '12). ACM, New York, NY, USA, 143-150. DOI=http://dx.doi.org/10.1145/23361276.2361304.

[27] Hamilton, M., Carbone, A., Gonsalvez, C., and Jollands, M. 2015. Breakfast with ICT Employers: What do they want to see in our graduates? In Proceedings of the 17th Australasian Computing Education Conference (ACE 2015). 29-36.

[28] How does a ministry ICT change the map? 2015. ACTI Chilean Association of Information Technology (June 2015). http://www.acti.cl/. Accessed 2015 Jul 05.

[29] A Guide to the Business Analysis Body of Knowledge: What is Business Analysis? 2015. International Institute of Business Analysis. http://www.iiba.org/babok-guide/babokguide-v2/babok-guide-online/chapter-one-introduction/1-2what-is-business-analysis.aspx. Accessed $2015 \mathrm{Jul} 08$.

[30] Impagliazzo, J. and McGettrick, A. 2007. New models for computing education. In Proceedings of the IEEE Frontiers In Education Conference (FIE 2007).

[31] IT Discipline, SIGITE; http://www.sigite.org/?page_id=22. Accessed $2015 \mathrm{Jul} 4$.

[32] Information Technology Curriculum Plan. 2015. Imam Muhammad Ibn Saud Islamic University; https://units.imamu.edu.sa/colleges/en/ComputerAndInforma tion/academic_department/Pages/IT_Curriculum_Plan_Bach elor.aspx. Accessed 2015 Jul 7.

[33] Information Technology Semester Curriculum. 2015. University of Cincinnati; http://cech.uc.edu/content/dam/cech/programs/it/docs/BSITFinal_2_20_2014.pdf. Accessed 2015 Jul 7.

[34] Information Technology Engineering. 2015. University De Mendoza; http://www.um.edu.ar/en/se/courses/informationtechnology-engineering.html, Accessed 2015 Jul 05.

[35] Alliance of Internet of things. 2015. A European initiative, SogetiLabs; http://labs.sogeti.com/alliance-of-internet-ofthings-for-innovation-a-european-initiative/\#more-64081. Accessed 2015 Jul 4.

[36] IT Market in Africa 2015-2019. Marketresearch.com (June 17, 2015). http://www.marketresearch.com/Infiniti-ResearchLimited-v2680/Africa-9083307/. Accessed 2015 Jul 05.

[37] IT Undergraduate Programs (USA). ACM Special Interest Group for Information Technology Education; http://www.sigite.org/?page_id=560. Accessed 2015 Jul 04.

[38] Jackson H., Hansen L., Tang L., Willemain J., and Ellis H. 2009. Changes to an IT program in response to the IT 2008 curriculum guidelines. In Proceedings of the 10th ACM SIGITE conference on SIG-information technology education (SIGITE’09). ACM, New York, NY, USA, 192-198.

[39] Kaczmarczyk, L. and Dopplick, R. 2014. Rebooting the Pathway to Success: Preparing Students for Computing Workforce Needs in the United States. ACM; http://pathways.acm.org. Accessed 2015 Jul 04. 
[40] Lunt B. and Ekstrom J. 2008. The IT model curriculum: a status update. In Proceedings of the 9th ACM SIGITE conference on Information technology education (SIGITE'08). ACM, New York, NY, USA, 1-4.

[41] Lunt, B.M., Ekstrom, J.J., Gorka, S., Hislop, G., Kamali, R., Lawson, E., LeBlanc, R., Miller, J. and Reichgelt, H. 2008. IT 2008: Curriculum Guidelines for Undergraduate Degree Programs in Information Technology; https://www.acm.org//education/curricula/IT2008\%20Curric ulum.pdf. Accessed 2015 Jul 04.

[42] Lunt B., Ekstrom J., Reichgelt H., Bailey M., and Leblanc R. 2010. IT 2008: the history of a new computing discipline. Communications of the ACM 53, 12 (December 2010): 133141.

[43] Lunt B. and Paterson B. An academic profile of IT faculty in the USA. In Proceedings of the 15th ACM SIGITE conference on Information technology education (SIGITE'14). ACM, New York, NY, USA, 163-166.

[44] Marshall D. 2006. What's IT worth? The Tiering of Canadian Degrees. Canadian Education Association; http://www.cea-ace.ca/sites/cea-ace.ca/files/EdCan-2006v46-n1-Marshall.pdf. Accessed 2015 Jul 06.

[45] Massy W. and Zemsky R. 1995. Using information to Enhance Academic Productivity, Educause, 1995; http://net.educause.edu/ir/library/html/nli0004.html. Accessed 2015 Jul 04.

[46] McGlade A. 2014. Why South Korea will be the next global hub for tech startups, Forbes (February 2014); http://www.forbes.com/sites/alanmcglade/2014/02/06/whysouth-korea-will-be-the-next-global-hub-for-tech-startups/. Accessed 2015 Jul 04.

[47] McLaughlin, P., Mills,A., Davis, P., Saha,S., Smith, P., Hardie,M. 2013. Lifelong Learning Pathways: Addressing Participation and Diversity in Higher Education, Final report. Office of Learning and Teaching, Sidney, N.S.W. http://www.olt.gov.au/resource-lifelong-learning-pathways. Accessed 2015 Jul 05.

[48] The national information technology talent training project. 2015. MIIT Project; http://baike.baidu.com/link?url=ztge5Px_oddSxC6MdfsXlet O900mbXqFvEyHzV1e3zzNe4tKIvpBVF_meEaDe3STRXh SeZQCLcqIvaCB6zk5oq. Accessed 2015 Jul 04.

[49] Mims, C. Forget 'the cloud'; 'the fog' is tech's future. 2014. The Wall Street Journal (May 2014); http://www.wsj.com/articles/SB10001424052702304908304 579566662320279406. Accessed 2015 Jul 06.

[50] National Institute of Standards and Technology; http://www.nist.gov/. Accessed 2015 Jul 04.

[51] The Integrated Postsecondary Education Data System (IPEDS) of the National Center for Education Statistics (NCES). https://surveys.nces.ed.gov/ipeds. Accessed 2015 Jul 04.
[52] Office for Learning and Teaching; http://www.olt.gov.au. Accessed 2015 Jul 04.

[53] O’Leary, D. 2014. Post-secondary accreditation: A Key differentiator when hiring new grads. IT World Canada (May 2014); http://www.itworldcanada.com/blog/post-secondaryaccreditation-a-key-differentiator-when-hiring-newgrads/93416. Accessed 2015 Jul 06.

[54] Partridge, H., Hanisch, J., Hughes, H., Henninger, M., Carroll, M., Combes, B., Genoni, P., Reynolds, S., Tanner,K., Burford, S., Ellis, L., Hider, P., Yates, C. 2011. Re-conceptualising and re-positioning Australian Library and Information Science Education for the $21^{\text {st }}$ Century. Australian Learning and Teaching Council, Sydney, NSW; http://www.liseducation.org.au/, Accessed 2015 Jul 05.

[55] Phillips, J. 2014. Project management definitions and solutions. CIO (March 2014);

http://www.cio.com/article/2439500/projectmanagement/project-management-definition-andsolutions.html. Accessed 2015 Jul 04.

[56] Plan of Study for Computer and Information Technology. 2015. Purdue Polytechnic; https://polytechnic.purdue.edu/degrees/computer-andinformation-technology/plan-of-study. Accessed 2015 Jul 7.

[57] Roman, C. 2011. Exploring the Cloud. Cloud Times (July 2011); http://cloudtimes.org/2011/07/04/exploring-thefuture-of-the-cloud/. Accessed $2015 \mathrm{Jul} 6$.

[58] Rouse, M. 2015. Information Technology, Tech Target.com; http://searchdatacenter.techtarget.com/definition/IT. Accessed 2015 Jul 04.

[59] Science and Technology in China (n.d.). In Wikipedia; https://en.wikipedia.org/wiki/Science_and_technology_in_C hina. Accessed 2015 Jul 05.

[60] Science and Technology in Israel. http://en.scio.pw/Science_and_technology_in_Israel Accessed 2015 Jul 06.

[61] Statistics Canada, Canada's national statistical agency; http://www.statcan.gc.ca. Accessed 2015 Jul 05.

[62] Tenenberg, J. 2014. Asking Research Questions: Theoretical Presuppositions. Transactions of Computing Education, 14, 3, Article 16 (September 2014).

[63] Wang, Z., Cai, Q., and Liu, M. 2008. Interpretation of and Consideration about Computing Curricula 2005. Sci-Tech Information Development \& Economy, 24, 163-166.

[64] Williams, J. 2004. IT education: more specialized in 2010. IT Professional, 6, 6, 18-20.

[65] Zhang, M. and Lo, V. 2010. Undergraduate computer science education in China. In Proceedings of the $41^{\text {st }}$ ACM technical symposium on computer science education (SIGCSE'10). ACM, New York, NY, USA, 396-400.

[66] Zhang, M. and Zhang, L. 2014. Undergraduate IT education in China. ACM Inroads, 5, 3 (September 2014), 49-55. 
APPENDIX

\section{A. FACULTY SURVEY \\ A.1 Faculty Survey Items}

F1 Country in which the main campus of my institution of higher learning exists

F2 Names of the department or academic unit

F3 Names of the computing degree programs in my department

F4 Total number of graduates from my undergraduate information technology (or closely related) degree program(s) over the past year is approximately: less than 100 students, Between 100 and 300 students, Between 300 and 500 students, Over 500 students

F5 Percent of graduating students who continue their studies in graduate school:

Less than $1 \%$, Between $1 \%$ and $10 \%$, Between $10 \%$ and $20 \%$, Over $20 \%$

F6 Areas of mathematics necessary to produce a competent IT graduate in the mid-2020s:

Statistics, Discrete mathematics, Probability, Linear algebra, Applied calculus, Business mathematics, Finite mathematics, Other

F7 Areas of mathematics currently required in the program to produce a competent IT graduate in the mid-2020:

Discrete mathematics, Statistics, Applied calculus, Linear algebra, Finite mathematics, Business mathematics, Other

F8 Number of math courses currently required in the program to produce a competent IT graduate:

$0,1,2,3,4,5,6,7,8$ or more

F9 Science subjects necessary to produce a competent IT graduate in the mid-2020s:

None (except Gen Ed), Physics, Biology, Chemistry, Geology, Other

F10 Science subjects currently required in the program to produce a competent IT graduate in the mid-2020:

None (except Gen Ed), Physics, Application Domain, Chemistry, Biology, Geology, Other

F11 Number of science subjects currently required in the program to produce a competent IT graduate:

$0,1,2,3,4,5$ or more

F12 A credit-bearing internship experience at the undergraduate information technology program:

Required, Optional, Not Offered

F13 The 8 most important areas you believe will be essential or fundamental for IT graduates to know in in the mid-2020s: Big Data, Cloud Computing, Cybersecurity: Digital Forensics and Response, Green Computing, Human Computer Interaction, Information Assurance and Cybersecurity, Information Management, Internet of Things, Integrative Programming Technologies, Networking, System Administration and Maintenance, System Integration and Architecture, Social and Professional Issues, Programming, Platform Technologies, Virtualization, Web Systems and Technologies, Other.

F14 The technical (IT) component of the full degree program is approximately for the undergraduate information technology (or closely related) degree program:

Less than $30 \%$ of the total program, Between $30 \%$ and $50 \%$ of the total program, Between $50 \%$ and $65 \%$ of the total program, Over $65 \%$ of the total program

F15 The principal source of significant external student transfers to the information technology (or closely related) program:

Few external transfer students, Transfers from two or three-year, Transfers due to life experiences, Industry-university articulation, Not sure/Not Available

\section{A.2 Faculty Survey Results}

1. The country in which the main campus of my institution of higher learning exists is: (589 responses)

\begin{tabular}{|c|c|c|c|c|c|}
\hline $\begin{array}{l}\text { United } \\
\text { States }\end{array}$ & 205 & $34.8 \%$ & Argentina & 3 & $0.5 \%$ \\
\hline Canada & 47 & $8.0 \%$ & Colombia & 3 & $"$ \\
\hline Australia & 42 & $7.1 \%$ & France & 3 & $"$ \\
\hline Brazil & 42 & $7.1 \%$ & Jordan & 3 & $"$ \\
\hline Germany & 26 & $4.4 \%$ & Poland & 3 & $"$ \\
\hline Spain & 22 & $3.7 \%$ & Bangladesh & 2 & $0.3 \%$ \\
\hline $\begin{array}{l}\text { United } \\
\text { Kingdom }\end{array}$ & 17 & $2.9 \%$ & Cyprus & 2 & $"$ \\
\hline China & 14 & $2.4 \%$ & Finland & 2 & $"$ \\
\hline Austria & 13 & $2.2 \%$ & Japan & 2 & $"$ \\
\hline Belgium & 13 & $2.2 \%$ & Macedonia & 2 & $"$ \\
\hline Greece & 11 & $1.9 \%$ & Sri lanka & 2 & $"$ \\
\hline Italy & 11 & $1.9 \%$ & Taiwan & 2 & $"$ \\
\hline Portugal & 11 & $1.9 \%$ & Albania & 1 & $0.2 \%$ \\
\hline India & 10 & $1.7 \%$ & Bahrain & 1 & $"$ \\
\hline South Africa & 9 & $1.5 \%$ & Croatia & 1 & $"$ \\
\hline Mexico & 8 & $1.4 \%$ & El Salvador & 1 & $"$ \\
\hline Bulgaria & 6 & $1.0 \%$ & Estonia & 1 & $"$ \\
\hline Chile & 6 & $"$ & Kenya & 1 & $"$ \\
\hline Denmark & 5 & $0.8 \%$ & Latvia & 1 & $"$ \\
\hline Ireland & 5 & $"$ & Netherlands & 1 & $"$ \\
\hline Malaysia & 5 & $"$ & Nigeria & 1 & $"$ \\
\hline $\begin{array}{c}\text { New } \\
\text { Zealand }\end{array}$ & 4 & $0.7 \%$ & Norway & 1 & $"$ \\
\hline Philippines & 4 & $"$ & Pakistan & 1 & $"$ \\
\hline Romania & 4 & $"$ & Singapore & 1 & $"$ \\
\hline Sweden & 4 & $"$ & & & \\
\hline Switzerland & 4 & $"$ & & & \\
\hline
\end{tabular}

2. The name of the department or academic unit (e.g., information technology, informatics, etc.) in which I have an appointment is: (A bewildering variety) 
3. The names of the computing degree programs in my department are:

(Also a bewildering variety, but of 589 responses)

at least one undergraduate program $\quad 581 \quad 98.6 \%$

at least one graduate program $\quad 458 \quad 77.8 \%$

4. The total number of graduates from my undergraduate information technology (or closely related) degree program(s) over the past year is approximately: (591 responses)

\begin{tabular}{|l|c|c|}
\hline Less than 100 students & 315 & $53.3 \%$ \\
\hline Between 100 and 300 students & 200 & $33.8 \%$ \\
\hline Between 300 and 500 students & 47 & $8.0 \%$ \\
\hline Over 500 students & 29 & $4.9 \%$ \\
\hline
\end{tabular}

5. The percent of graduating students from my undergraduate information technology (or closely related) degree program who continue their studies in graduate school is approximately: (591 responses)

\begin{tabular}{|l|c|c|}
\hline Less than $1 \%$ & 49 & $8.3 \%$ \\
\hline Between $1 \%$ and $10 \%$ & 270 & $45.7 \%$ \\
\hline Between $10 \%$ and $20 \%$ & 134 & $22.7 \%$ \\
\hline Over $20 \%$ & 138 & $23.4 \%$ \\
\hline
\end{tabular}

6. For a strong and rigorous undergraduate degree program in information technology, indicate the areas of mathematics you believe are necessary to produce a competent IT graduate in the mid-2020s. Check all that apply. (542 responses)

\begin{tabular}{|l|c|c|}
\hline Statistics & 447 & $82.5 \%$ \\
\hline Discrete mathematics & 440 & $81.2 \%$ \\
\hline Probability & 363 & $67.0 \%$ \\
\hline Linear algebra & 275 & $50.7 \%$ \\
\hline Applied calculus & 266 & $49.1 \%$ \\
\hline Business mathematics & 154 & $28.4 \%$ \\
\hline Finite mathematics & 149 & $27.5 \%$ \\
\hline Other & 41 & $7.6 \%$ \\
\hline
\end{tabular}

7. Which areas of mathematics does your program currently require to produce a competent IT graduate? (530 responses)

\begin{tabular}{|l|c|c|}
\hline Discrete mathematics & 395 & $74.5 \%$ \\
\hline Statistics & 374 & $70.6 \%$ \\
\hline Applied calculus & 318 & $60.0 \%$ \\
\hline Linear algebra & 288 & $54.3 \%$ \\
\hline Probability & 286 & $54.0 \%$ \\
\hline Finite mathematics & 110 & $20.8 \%$ \\
\hline Business mathematics & 82 & $15.5 \%$ \\
\hline Other & 54 & $10.2 \%$ \\
\hline
\end{tabular}

8 . How many math courses does your program currently require to produce a competent IT graduate? (541 responses)

\begin{tabular}{|c|c|c|}
\hline 0 & 24 & $4.4 \%$ \\
\hline 1 & 66 & $12.2 \%$ \\
\hline 2 & 98 & $18.1 \%$ \\
\hline 3 & 125 & $23.1 \%$ \\
\hline 4 & 135 & $25.0 \%$ \\
\hline 5 & 30 & $5.5 \%$ \\
\hline 6 & 39 & $7.2 \%$ \\
\hline 7 & 24 & $4.4 \%$ \\
\hline 8 or more & 11 & $2.0 \%$ \\
\hline
\end{tabular}

9. For a strong and rigorous undergraduate degree program in information technology, indicate the science subjects you believe are necessary to produce a competent IT graduate in the mid2020s. Check all that apply. (535 responses)

\begin{tabular}{|l|c|c|}
\hline $\begin{array}{c}\text { None (except } \\
\text { General Education) }\end{array}$ & 270 & $50.5 \%$ \\
\hline Physics & 219 & $40.9 \%$ \\
\hline Other & 74 & $13.8 \%$ \\
\hline Biology & 68 & $12.7 \%$ \\
\hline Chemistry & 38 & $7.1 \%$ \\
\hline Geology & 18 & $3.4 \%$ \\
\hline
\end{tabular}


10. Which science subjects does your program currently require to produce a competent IT graduate? (546 responses)

\begin{tabular}{|l|c|c|}
\hline None (except Gen Ed) & 243 & $44.5 \%$ \\
\hline Physics & 171 & $31.3 \%$ \\
\hline Application Domain & 111 & $20.3 \%$ \\
\hline Other & 69 & $12.6 \%$ \\
\hline Chemistry & 55 & $10.1 \%$ \\
\hline Biology & 27 & $4.9 \%$ \\
\hline Geology & 10 & $1.8 \%$ \\
\hline
\end{tabular}

11. How many science courses does your program currently require to produce a competent IT graduate? (533 responses)

\begin{tabular}{|c|c|c|}
\hline 0 & 124 & $23.3 \%$ \\
\hline 1 & 110 & $20.6 \%$ \\
\hline 2 & 149 & $28.0 \%$ \\
\hline 3 & 80 & $15.0 \%$ \\
\hline 5 or more & 58 & $10.9 \%$ \\
\hline
\end{tabular}

12. For the undergraduate information technology program at my institution, a credit-bearing internship experience is: (541 respondents)

\begin{tabular}{|l|c|c|}
\hline Required & 173 & $32.0 \%$ \\
\hline Optional & 273 & $50.5 \%$ \\
\hline Not Offered & 95 & $17.6 \%$ \\
\hline
\end{tabular}

13. Consider the following list of knowledge areas for information technology as developed by the IT2017 Task Group. Indicate the 8 most important areas you believe will be essential or fundamental for IT graduates to know in the mid-2020s. (541 respondents: Top 8 in bold font)

\begin{tabular}{|c|c|c|}
\hline Big Data & 353 & $65.2 \%$ \\
\hline Cloud Computing & 342 & $63.2 \%$ \\
\hline Cybersecurity: Digital Forensics and Response & 271 & $50.1 \%$ \\
\hline Green Computing & 79 & $14.6 \%$ \\
\hline Human Computer Interaction & 328 & $60.6 \%$ \\
\hline Information Assurance and Cybersecurity & 310 & $57.3 \%$ \\
\hline Information Management & 275 & $50.8 \%$ \\
\hline Internet of Things & 182 & $33.6 \%$ \\
\hline Integrative Programming Technologies & 130 & $24.0 \%$ \\
\hline Networking & 368 & $68.0 \%$ \\
\hline System Administration and Maintenance & 181 & $33.5 \%$ \\
\hline System Integration and Architecture & 233 & $43.1 \%$ \\
\hline Social and Professional Issues & 205 & $37.9 \%$ \\
\hline Programming & 443 & $81.9 \%$ \\
\hline Platform Technologies & 86 & $15.9 \%$ \\
\hline Virtualization & 176 & $32.5 \%$ \\
\hline Web Systems and Technologies & 405 & $74.9 \%$ \\
\hline Other & 86 & $15.9 \%$ \\
\hline
\end{tabular}

14. For the undergraduate information technology (or closely related) degree program at your institution, the technical (IT) component of the full degree program is approximately: (541 responses)

\begin{tabular}{|l|c|c|}
\hline Less than $30 \%$ of the total program & 75 & $13.9 \%$ \\
\hline Between $30 \%$ and $50 \%$ of the total program & 150 & $27.7 \%$ \\
\hline Between $50 \%$ and $65 \%$ of the total program & 179 & $33.1 \%$ \\
\hline Over $65 \%$ of the total program & 137 & $25.3 \%$ \\
\hline
\end{tabular}


15. Excluding first-time admission to an undergraduate program, indicate the principal source of significant external student transfers to the information technology (or closely related) program at your institution. (537 responses)

\begin{tabular}{|l|c|c|}
\hline Few external transfer students & 187 & $34.8 \%$ \\
\hline Transfers from two or three-year & 177 & $33.0 \%$ \\
\hline Transfers due to life experiences & 43 & $8.0 \%$ \\
\hline Industry-university articulation & 18 & $3.4 \%$ \\
\hline Not sure/Not Available & 112 & $20.9 \%$ \\
\hline
\end{tabular}

\section{B. INDUSTRY SURVEY B.1 Industry Survey Items}

\begin{tabular}{|l|l|}
\hline I1 & Country in which the mail location of my company exists is .. \\
\hline I2 & Name of the IT department or unit in which I work is ... \\
\hline I3 & $\begin{array}{l}\text { The most recent total number of employees from my IT department } \\
\text { is approximately: } \\
\text { Less than } 10 \text { employees, Between } 10 \text { and } 30 \text { employees, Between } 30 \\
\text { and } 50 \text { employees, Between } 50 \text { and } 100 \text { employees, Over 100 } \\
\text { employees. }\end{array}$ \\
\hline I4 & $\begin{array}{l}\text { Areas of mathematics necessary to produce a competent IT graduate } \\
\text { in the mid-2020s: } \\
\text { Statistics, Financial modeling and budgeting, Business } \\
\text { mathematics/calculus, Probability, Linear algebra, Discrete } \\
\text { mathematics, Applied calculus, Finite mathematics, Other. }\end{array}$ \\
\hline I5 & $\begin{array}{l}\text { Science subjects necessary to produce a competent IT graduate in the } \\
\text { mid-2020s: } \\
\text { Physics, Chemistry, Biology, Geology, Other }\end{array}$ \\
\hline I6 & $\begin{array}{l}\text { The 8 MOST IMPORTANT AREAS you believe will be essential or } \\
\text { fundamental for IT graduates to know in in the mid-2020s: } \\
\text { Big Data, Cloud Computing, Cybersecurity: Digital Forensics and } \\
\text { Response, Green Computing, Human Computer Interaction, } \\
\text { Information Assurance and Cybersecurity, Information } \\
\text { Management, Internet of Things, Integrative Programming } \\
\text { Technologies, Networking, System Administration and } \\
\text { Maintenance, System Integration and Architecture, Social and } \\
\text { Professional Issues, Programming, Platform Technologies, } \\
\text { Virtualization, Web Systems and Technologies, Other. }\end{array}$ \\
\hline I7 & $\begin{array}{l}\text { The top six skill sets will require of new IT graduates in the mid- } \\
\text { 2020s: } \\
\text { Project management, Cloud Computing, Business analytics, Data } \\
\text { analytics, Database administration and architecture, Information } \\
\text { (cyber) security, Quality assurance, PC/desktop support, } \\
\text { Networking, Programming, Help desk support, Soft skills, } \\
\text { Rudiments of finance, Other. }\end{array}$ \\
\hline
\end{tabular}

\section{B2. Industry Survey Results}

1. The Country in which the mail location of my company exists is: (of 91 responses)

\begin{tabular}{|l|c|c|}
\hline United States & 90 & $98.9 \%$ \\
\hline Nigeria & 1 & $1.1 \%$ \\
\hline
\end{tabular}

2. The name of the IT department or unit in which I work is: (A bewildering variety)

3. The most recent total number of employees from my IT department is approximately: (91 responses)

\begin{tabular}{|l|c|c|}
\hline Less than 10 employees & 41 & $45.1 \%$ \\
\hline Between 10 and 30 employees & 18 & $19.8 \%$ \\
\hline Between 30 and 50 employees & 5 & $5.5 \%$ \\
\hline Between 50 and 100 employees & 7 & $7.7 \%$ \\
\hline Over 100 employees & 20 & $22.0 \%$ \\
\hline
\end{tabular}

4. For a strong and rigorous undergraduate degree program in information technology, indicate the areas of mathematics you believe are necessary to produce a competent IT graduate in the mid-2020s. Check all that apply. (91 responses)

\begin{tabular}{|l|c|c|}
\hline Statistics & 68 & $74.7 \%$ \\
\hline Financial modeling and budgeting & 62 & $68.1 \%$ \\
\hline Business mathematics/calculus & 61 & $67.0 \%$ \\
\hline Probability & 46 & $50.5 \%$ \\
\hline Linear algebra & 26 & $28.6 \%$ \\
\hline Discrete mathematics & 25 & $27.5 \%$ \\
\hline Applied calculus & 20 & $22.0 \%$ \\
\hline Finite mathematics & 18 & $19.8 \%$ \\
\hline Other & 10 & $11.0 \%$ \\
\hline
\end{tabular}

5. For a strong and rigorous undergraduate degree program in information technology, indicate the science subjects you believe are necessary to produce a competent IT graduate in the mid- 2020s. Check all that apply. (91 responses)

\begin{tabular}{|l|c|c|}
\hline Physics & 51 & $56.0 \%$ \\
\hline Other & 41 & $45.1 \%$ \\
\hline Chemistry & 23 & $25.3 \%$ \\
\hline Biology & 14 & $15.4 \%$ \\
\hline Geology & 3 & $3.3 \%$ \\
\hline
\end{tabular}


6. Consider the following list of knowledge areas for information technology as developed by the IT2017 Task Group. Indicate the eight most important areas you believe will be essential or fundamental for IT graduates to know in the mid2020s. (91 responses, Top eight in bold)

\begin{tabular}{|l|c|c|}
\hline Big Data & 44 & $48.4 \%$ \\
\hline Cloud Computing & 59 & $64.8 \%$ \\
\hline Cybersecurity and Digital Forensics & 68 & $74.7 \%$ \\
\hline Green Computing & 18 & $19.8 \%$ \\
\hline Human Computer Interaction & 41 & $45.1 \%$ \\
\hline Information Assurance and Security & $\mathbf{5 4}$ & $\mathbf{5 9 . 3 \%}$ \\
\hline Information Management & 53 & $58.2 \%$ \\
\hline Internet of Things & 34 & $37.4 \%$ \\
\hline Integrative Programming Technologies & 26 & $28.6 \%$ \\
\hline Networking & 50 & $54.9 \%$ \\
\hline System Administration and Maintenance & 33 & $36.3 \%$ \\
\hline System Integration and Architecture & 55 & $60.4 \%$ \\
\hline Social and Professional Issues & 45 & $49.5 \%$ \\
\hline Programming & 45 & $49.5 \%$ \\
\hline Platform Technologies & 20 & $22.0 \%$ \\
\hline Virtualization & 55 & $60.4 \%$ \\
\hline Web Systems and Technologies & 58 & $63.7 \%$ \\
\hline Other & 6 & $6.6 \%$ \\
\hline
\end{tabular}

7. Indicate the top six skill sets you believe your organization will require of new IT graduates in the mid-2020s. (91 responses, Top six in bold)

\begin{tabular}{|c|c|c|}
\hline Project management & 71 & $78.0 \%$ \\
\hline Cloud Computing & 39 & $42.9 \%$ \\
\hline Business analytics & 54 & $59.3 \%$ \\
\hline Data analytics & 45 & $49.5 \%$ \\
\hline $\begin{array}{l}\text { Database administration and } \\
\text { architecture }\end{array}$ & 47 & $51.6 \%$ \\
\hline Information (cyber) security & 67 & $73.6 \%$ \\
\hline Quality assurance & 22 & $24.2 \%$ \\
\hline PC/desktop support & 21 & $23.1 \%$ \\
\hline Networking & 41 & $45.1 \%$ \\
\hline Programming & 37 & $40.7 \%$ \\
\hline Helpdesk support & 23 & $25.3 \%$ \\
\hline Soft skills & 59 & $64.8 \%$ \\
\hline Rudiments of finance & 21 & $23.1 \%$ \\
\hline Other & 10 & $11.0 \%$ \\
\hline
\end{tabular}

\section{FACULTY SURVEY DATA ON SOURCES OF EXTERNAL TRANSFER STUDENTS}

Table C.1: Transfer into programs by program size, for demanding ( $1^{\text {st }}$ row) and all $\left(2^{\text {nd }}\right.$ row $)$ programs

\begin{tabular}{|l|c|c|c|c|}
\hline & \multicolumn{4}{|c|}{ Number of graduates in 2014-2015 } \\
\hline \multicolumn{1}{|c|}{ Transfer Source } & $\begin{array}{c}<= \\
\mathbf{1 0 0}\end{array}$ & $\begin{array}{c}\mathbf{1 0 0} \\
\mathbf{3 0 0}\end{array}$ & $\mathbf{3 0 0 - 5 0 0}$ & $>\mathbf{5 0 0}$ \\
\hline $\begin{array}{l}\text { No significant number } \\
\text { of external transfer } \\
\text { students }\end{array}$ & $28 / 52 \%$ & $17 / 53 \%$ & $8 / 80 \%$ & $5 / 56 \%$ \\
\hline $\begin{array}{l}\text { Transfers from two-year } \\
\text { or three-year technical } \\
\text { institutes or community } \\
\text { colleges }\end{array}$ & $16 / 30 \%$ & $8 / 25 \%$ & $2 / 20 \%$ & $3 / 33 \%$ \\
\hline $\begin{array}{l}\text { External transfers due to } \\
\text { life experiences }\end{array}$ & $5 / 9 \%$ & $4 / 13 \%$ & 0 & 0 \\
\hline $\begin{array}{l}\text { Industry-university } \\
\text { articulation agreements }\end{array}$ & $5 / 4 \%$ & $3 / 9 \%$ & 0 & $1 / 11 \%$ \\
\hline
\end{tabular}


Table C.2: Transfer into programs by program technical content for demanding $\left(1^{\text {st }}\right.$ row, red $)$ and all $\left(2^{\text {nd }}\right.$ row, blue $)$ programs

\begin{tabular}{|c|c|c|c|c|}
\hline & \multicolumn{4}{|c|}{$\begin{array}{l}\% \text { of total degree program } \\
\text { that is technical }\end{array}$} \\
\hline Transfer source & $<30 \%$ & $\begin{array}{c}30- \\
50 \%\end{array}$ & $\begin{array}{l}50- \\
65 \%\end{array}$ & $>65 \%$ \\
\hline $\begin{array}{l}\text { No significant number of } \\
\text { external transfer students }\end{array}$ & $\begin{array}{c}28 / \\
44 \%\end{array}$ & $\begin{array}{c}44 / \\
35 \%\end{array}$ & $\begin{array}{l}36 / 54 \% \\
55 / 41 \%\end{array}$ & $\begin{array}{l}22 / 58 \% \\
60 / 59 \%\end{array}$ \\
\hline $\begin{array}{l}\text { Transfers from two-year } \\
\text { or three-year technical } \\
\text { institutes or community } \\
\text { colleges }\end{array}$ & $\begin{array}{c}26 / \\
41 \%\end{array}$ & $\begin{array}{c}66 / \\
52 \%\end{array}$ & $\begin{array}{l}21 / 31 \% \\
58 / 43 \%\end{array}$ & $\begin{array}{l}8 / 21 \% \\
27 / 26 \%\end{array}$ \\
\hline $\begin{array}{l}\text { External transfers due to } \\
\text { life experiences }\end{array}$ & $\begin{array}{c}8 / \\
13 \%\end{array}$ & $\begin{array}{l}10 / \\
8 \%\end{array}$ & $\begin{array}{c}6 / 9 \% \\
15 / 11 \%\end{array}$ & $3 / 8 \%$ \\
\hline $\begin{array}{l}\text { Industry-university } \\
\text { articulation agreements }\end{array}$ & $\begin{array}{c}1 / \\
2 \%\end{array}$ & $\begin{array}{c}6 / \\
5 \%\end{array}$ & $\begin{array}{l}4 / 6 \% \\
6 / 4 \%\end{array}$ & $\begin{array}{c}5 / 13 \% \\
5 / 5 \%\end{array}$ \\
\hline
\end{tabular}

\section{MEMBER ORGANIZATIONS FROM FEAPO}

Association for Computing Machinery (ACM) https://www.acm.org/ Association of Enterprise Architects (AEA) https://www.globalaea.org/ Association for Enterprise Information http://www.afei.org/ Association of IT Professionals (AITP) https://www.aitp.org/
ASIS\&T - Association for Information Science \& Technology https://www.asist.org

Australian Computer Society (ACS) https://www.acs.org.au/ British Computer Society (BCS) http://www.bcs.org/ Business Architecture Guild http://www.businessarchitectureguild.org/ Canadian Information Processing Society (CIPS) http://www.cips.ca/ Center for the Advancement of the Enterprise Architecture Profession (CAEAP) http://www.caeap.org/

Data Management Association (DAMA) http://www.dama.org/

DGI - Data Governance Institute www.datagovernance.com

Federation of EA Professional Organizations (FEAPO) http://feapo.org/

The Global IT Community Association www.gitca.org

IEEE Computer Society http://www.computer.org/web/csdl/

The International Federation for Information Processing, IFIP http://www.ifip.org/

IFIP/ International Professional Practice Partnership, IP3 http://ipthree.org/

Information Architecture Institute http://iainstitute.org/

Information Systems Audit and Control Association (ISACA) www.isaca.org

International Information System Security Certification Consortium (ISC) $)^{2}$ https://www.isc2.org/

International Association of Software Architects (IASA) http://iasaglobal.org/

International Council on Systems Engineering (INCOSE) www.incose.org/

International Institute of Business Analysis http://www.iiba.org/ Institute of Information Technology Professionals New Zealand Institute for EA Development http://www.enterprise-architecture.info/ The National Association of State Chief Information Officers Netherlands Architecture Forum http://www.naf.nl/

The Network Professional Association http://www.npa.org/ Object Management Group http://www.omg.org/

SOA Institute http://www.soainstitute.org/

Software Engineering Institute (SEI) http://www.sei.cmu.edu/ Society for Information Management https://www.simnet.org/ 